\title{
The essential mitotic peptidyl-prolyl isomerase Pin1 binds and regulates mitosis-specific phosphoproteins
}

\author{
Minhui Shen, ${ }^{1,2}$ P. Todd Stukenberg ${ }^{2,3}$ Marc W. Kirschner, ${ }^{3}$ and Kun Ping Lu ${ }^{1,4}$ \\ ${ }^{1}$ Cancer Biology Program, Division of Hematology/Oncology, Department of M edicine, Beth Israel Deaconess Medical \\ Center and Division on Aging, Harvard Medical School, Boston, Massachusetts 02215 USA; ${ }^{3}$ Department of Cell Biology, \\ Harvard Medical School, Boston, Massachusetts 02115 USA
}

\begin{abstract}
Phosphorylation of mitotic proteins on the Ser/Thr-Pro motifs has been shown to play an important role in regulating mitotic progression. Pin1 is a novel essential peptidyl-prolyl isomerase (PPIase) that inhibits entry into mitosis and is also required for proper progression through mitosis, but its substrate(s) and function(s) remain to be determined. Here we report that in both human cells and Xenopus extracts, Pin1 interacts directly with a subset of mitotic phosphoproteins on phosphorylated Ser/Thr-Pro motifs in a phosphorylation-dependent and mitosis-specific manner. Many of these Pin1-binding proteins are also recognized by the monoclonal antibody MPM-2, and they include the important mitotic regulators Cdc25, Myt1, Weel, PIk1, and Cdc27. The importance of this Pin1 interaction was tested by constructing two Pin1 active site point mutants that fail to bind a phosphorylated Ser/Thr-Pro motif in mitotic phosphoproteins. Wild-type, but not mutant, Pin1 inhibits both mitotic division in Xenopus embryos and entry into mitosis in Xenopus extracts. We have examined the interaction between Pin1 and Cdc25 in detail. Pin1 not only binds the mitotic form of Cdc25 on the phosphorylation sites important for its activity in vitro and in vivo, but it also inhi bits its activity, offering one explanation for the ability of Pin1 to inhibit mitotic entry. In a separate paper, we have shown that Pin1 is a phosphorylation-dependent PPlase that can recognize specifically the phosphorylated Ser/Thr-Pro bonds present in mitotic phosphoproteins. Thus, Pin1 likely acts as a general regulator of mitotic proteins that have been phosphorylated by Cdc2 and other mitotic kinases.
\end{abstract}

[Key Words: Cdc2; cell cycle control; mitosis; peptidyl-prolyl isomerase; phosphoproteins; Pin1]

Received August 7, 1997; revised version accepted January 5, 1998.

Events of the eukaryotic cell cycle are regulated by an evolutionarily conserved set of protein kinases. The cyclin-dependent kinases (Cdks) are important for driving cells through different phases of the cell cycle and their sequential activation and inactivation are tightly regulated (for review, see Coleman and Dunphy 1994; King et al. 1994; N urse 1994). At the $G_{2} / M$ transition, activation of the mitotic $\mathrm{Cdk} C \mathrm{Cdc} 2$ requires multiple events; these incl ude the synthesis and binding of cyclin B, phosphorylation on $\mathrm{Cdc} 2$ at a site by CDK-activating kinase (CAK) and, finally, Cdc25 activating sites that have been phosphorylated by Weel and M yt1 (for review, see Coleman and Dunphy 1994; King et al. 1994; N urse 1994).

How activation of a Cdk elicits the downstream events of cell cycle progression is less well understood. Activation of cyclin B/Cdc2 leads to the phosphorylation of a large number of proteins, mainly on sites containing a Ser/Thr-Pro motif (for review, see Nigg 1995).

\footnotetext{
2These authors contributed equally to this work.

${ }^{4}$ Corresponding author.

E-MAIL klu@bidmc.harvard.edu; FAX (617) 667-0610.
}

Protein phosphorylation is believed to alter the functions of proteins to trigger the events of mitosis. In a few cases, mitotic phosphorylation has been shown to regulate mitotic events (Heal d and M cKeon 1990; Bailly et al. 1991; Blangy et al. 1995); however, it is not understood how the rapid changes in mitotic phosphorylation are converted to the sequential events of mitosis.

An important experimental tool that has uncovered the general role of phosphorylation in mitotic regulation is the MPM-2 (mitotic phosphoprotein monoclonal-2) antibody (Davis et al. 1983). MPM -2 recognizes a phosphorylated Ser/Thr-Pro epitope on 50 proteins, which are localized to various mitotic structures (Vandre et al. 1986; Westendorf et al. 1994; M atsumoto-Taniura et al. 1996). Several important mitotic regulators are recognized by this antibody, including Cdc25, Weel, topoisomerase IIa, Cdc27, Map 4, inner centromere proteins (IN CEN P), and N IMA (never in mitosis A) (Vandre et al. 1991; T aagepera et al. 1993; C̄oleman et al. 1993; Kuang et al. 1994; King et al. 1995; Mueller et al . 1995; Ye et al. 1995; Stukenberg et al. 1997). Currently six kinases have been shown to phosphorylate proteins in vitro to pro- 
duce the M PM-2 epitope: Cdc2, Polo-like kinase (PIk1), NIMA, MAP kinase, a MAP kinase kinase (MEK), and an unidentified activity ME-H (Kuang and Ashorn 1993; Taagepera et al . 1994; Kumagai and Dunphy 1996; Renzi et al. 1997). However, these kinases also phosphorylate substrates that do not generate the M PM -2 epitope especially in cell cycle stages other than mitosis. This suggests that additional features are required for the recognition by M PM -2. Determination of the optimal M PM-2binding sequence have confirmed the importance of amino acid residues flanking the phosphorylated Ser/ Thr-Pro motif for the M PM-2 recognition (Westendorf et al. 1994; Y affe et al. 1997).

The identification of the novel human mitotic regulator Pin1 suggests a new regulatory mechanism for mitotic regulation (Lu et al. 1996). Pinl was identified originally in a yeast two-hybrid screen as a protein that interacts with the essential mitotic kinase NIMA and suppresses its mitosis-promoting activity ( $\mathrm{Lu}$ et al. 1996). Although a NIMA-like pathway is also required for the $G_{2} / M$ transition in vertebrate cells ( $L u$ and Hunter 1995), it has been difficult to identify metazoan N IM A functional homologs. In contrast, Pin1 has been identified in all eukaryotic organisms where examined, including plants, yeast, Aspergillus, and mammals (Hanes et al. 1989; Lu et al. 1996; Maleszka et al. 1996; sequences have been deposited in GenBank under accession nos. 1688322 and 2739197). Pin1 is an essential peptidyl-prolyl cis-trans isomerase (PPlase). It is distinct from two other well-characterized PPIase families: the cyclophilins and the FK506-binding proteins (FKBPs), which are targets for the immunosuppressive drugs cyclosporin A and FK506, respectively (for review, see Schreiber 1991; Fischer 1994; Schmid 1995). PPIases are ubiquitous enzymes that catalyze rotation about the pepti de bond preceding a Pro residue, and may accel erate the folding and trafficking of some proteins (for review, see Schmid 1995). Interestingly, inhibition of PPIase activity is not required for the immunosuppressive property of cyclosporin A and FK506. Furthermore, neither the cyclophilins nor the FKBPs are essential for normal cell growth (Schreiber 1991; Fischer 1994; Schmid 1995). Thus, evidence for the biological importance of PPIase enzymatic activity has been limited.

In contrast, Pin1 contains a PPIase domain that is essential for cell cycle progression and its subcellular localization is tightly regulated at the $\mathrm{G}_{2} / \mathrm{M}$ transition ( $\mathrm{Lu}$ et al. 1996). Pin1 is localized in a defined nuclear substructure in interphase, but is concentrated to the condensed chromatin, with some staining in other structures during mitosis. Furthermore, depletion of Pin1 protein in HeLa cells or Pin1/Esslp in yeast results in mitotic arrest, whereas overexpression of Pin1 induces a $\mathrm{G}_{2}$ arrest (Lu et al . 1996). These results suggest that Pin1 is an essential mitotic regulator that both regulates negatively entry into mitosis and is required for progression through mitosis.

The crystal structure of human Pin1 complexed with an Ala-Pro dipeptide suggests that the isomerization mechanism of Pin1 includes general acid-base and cova- lent catalysis during peptide bond isomerization (Ranganathan et al. 1997). More interesting, Pin1 displays a unique substrate specificity. It prefers an acidic residue amino-terminal to the isomerized Pro bond attributable to interaction of the acidic side chain with a basi c cluster in Pin1. This basic cluster consists of the highly conserved residues Lys-63, Arg-68, and Arg-69 at the entrance to the active site. In the crystal structure, this conserved triad sequestered a sulfate ion in close proximity to the $\beta$-methyl group of the Ala residue in the bound Ala-Pro dipeptide. Because a logical candidate for this negatively charged residue would be a phosphorylated Ser/Thr, we have hypothesized previously that Pin1 may recognize its substrates in a phosphorylationdependent manner (Ranganathan et al. 1997). Recently, we have further shown that Pinl is a sequence-specific and phosphorylation-dependent PPIase that can recognize the phosphorylated Ser/Thr-Pro bonds specifically present in mitotic phosphoproteins (Yaffe et al. 1997). However, little is known about the identity of Pin1 target proteins and the role, if any, of Pin1 in regulating these proteins.

To address the above questions, we identified Pin1binding proteins in human cells and Xenopus extracts. Our results indicate that although Pin1 levels are constant throughout the cell cycle, the interaction of Pinl and its targets is cell cycle regulated and depends on mitotic phosphorylation of target proteins. Pin1 interacts directly with a large subset of mitosis-specific phosphoproteins, which includes Cdc25, Weel, Myt1, PIk1, Cdc27, and E-MAP115, as well as some others recently identified by a screen for mitotic phosphoproteins (Stukenberg et al. 1997). Many of these Pin1-interacting proteins are also recognized by the M PM-2 antibody. In functional assays, microinjection of Pinl inhibits mitotic division in Xenopus embryos and entry into mitosis in Xenopus extracts, as is the case in HeLa and yeast cells. Furthermore, Pinl binds the mitotically phosphorylated form of C dc25 in vitro and in vivo, and it binds C dc 25 on the important phosphorylation sites and inhibits its activity. This characterization of the Pin1-Cdc25 interaction can explain at least partially the ability of Pin1 to inhibit the $G_{2} / M$ transition. All of these activities of Pin1 are dependent on the ability of Pin1 to mitotic phosphoproteins, as the activities are disrupted by point mutations that inhibit the ability of Pin1 to recognize this unique class of phosphoproteins. These results suggest that Pin1 acts as a general regulator of mitosis-specific phosphoproteins, presumably by catalyzing phosphorylation-dependent Pro isomerization.

\section{Results}

Pin1 levels are constant through the cell cycle

Whereas overexpression of Pin1 results in $G_{2}$ arrest, depletion of Pin1 induces mitotic arrest without affecting DNA synthesis (Lu et al. 1996). To determine the basis for this cell cycle specificity, we first asked 
whether Pin1 protein level fluctuated during the cell cycle. To address this question, HeLa cells were synchronized at the $\mathrm{G}_{1} / \mathrm{S}$ boundary. At different times after the release from the block, cells were harvested and analyzed by flow cytometry or lysed and analyzed for protein expression by immunoblotting. Analysis of DNA content and cyclin B1 levels indicated that the HeLa cells progressed synchronously through different phases of the cell cycle (Fig. 1A and B), as shown previously (Heintz et al. 1983). Total Pin1 levels did not change significantly during the cell cycle (Fig. 1B). The total cellular Pin1 concentration in HeLa cells was esti mated to be $\sim 0.5 \mu \mathrm{m}$, based on immunoblotting analysis using anti-Pin1 antibodies with recombinant Pinl protein as a standard (data not shown).

A

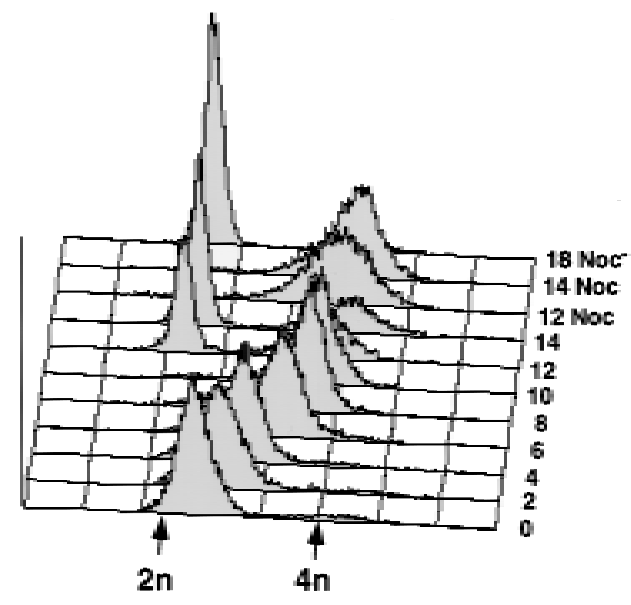

B Time After Release (hr)
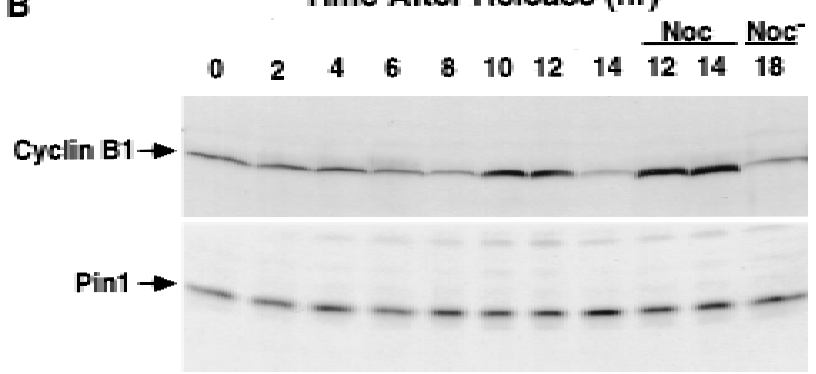

Figure 1. Pinl levels are constant during the cell cycle. HeLa cells were synchronized at the $G_{1} / S$ boundary by double thymidine and aphidicolin block and released to enter the cell cycle. To block cells at mitosis, nocodazole ( $\mathrm{N} \mathrm{oc}, 50 \mathrm{ng} / \mathrm{ml}$ ) was added to cells at $8 \mathrm{hr}$ after the rel ease and incubated for another $4 \mathrm{hr}(12 \mathrm{~N} \mathrm{oc})$ or $6 \mathrm{hr}$ (14 Noc). To obtain pure $\mathrm{G}_{1}$ cells, mitosisarrested cells ( $14 \mathrm{~N} \mathrm{oc}$ ) were plated in a nocodazole-free media for another $4 \mathrm{hr}\left(18 \mathrm{~N} \mathrm{oc}^{-}\right)$. Cells were harvested at the indicated times and al iquots were subjected to flow cytometric analysis to determine the cell cycle status; the remaining cells were lysed in RIPA buffer. The same amount of total proteins were separated on a SDS-containing gel, transferred to a membrane that was cut into three pieces and probed with anti-cyclin B, antiCdc2, and anti-Pin1 antibodies, respectively. Cdc2 levels were similar in all lanes (data not shown).(A) Flow cytometric analysis of the DN A content; (B) immunobl ot analysis of cyclin band Pin1 protein levels.
Pin1 directly binds a subset of conserved mitotic phosphoproteins

Because the levels of Pinl do not fluctuate during the cell cycle, its mitosis-specific function is likely conferred by some other mechanisms. Therefore, we tested for a cell cycle-dependent interaction between Pin1 and its binding proteins. A glutathione S-transferase (GST) fusion protein containing full-length Pin1 was bacterially expressed, purified, and then used to probe for interacting proteins in S-phase, mitosis, or $\mathrm{G}_{1}$-phase by Farwestern analysis. As shown in Figure 2A, the ability of Pinl to interact with cellular proteins remained relatively low during S-phase, increased when cells progressed through $\mathrm{G}_{2} / \mathrm{M}$ (10-hr point), and was almost completely lost when cells moved to the next $\mathrm{G}_{1}$ (14-hr point). However, if cells were not allowed to progress into the next cell cycle but, rather, were blocked at mitosis by adding nocodazole $(14+\mathrm{N})$, Pin1-binding activity increased even further (Fig. 2A). Because the binding activity was detected using denatured proteins, the protein-protein interaction between Pinl and these proteins must be direct. To examine whether this Pinl interaction with its target proteins occur under nondenaturing conditions and to estimate the number of Pin1-interacting proteins, glutathione beads containing GST and GST-Pin1 were incubated with interphase and mitotic extracts, and beads were extensively washed and proteins bound to beads were separated on SDS-containing gels and stained with Coomassie blue. Whereas no detectable proteins were precipitated by GST beads from either interphase or mitotic extracts (data not shown), GST-Pin1 beads specifically precipitated $\sim 30$ clearly Coomassie-stainable bands from mitotic extracts, but only four to seven minor bands from interphase extracts (Fig. 2B). These two results together indicate that Pin1 interacts mainly with a subset of proteins in a mitosisspecific manner.

Recently we have shown that both Pin1 and MPM-2 bind similar peptides containing phosphorylated Ser-Pro flanked by hydrophobic residues or A rg, and that many, but not all, of the mitotic proteins precipitated by GSTPin 1 are al so recognized by the M PM -2 antibody (Y affe et al. 1997) (Figs. 2B and 3C), suggesting a possi ble interaction between Pin1 and M PM-2 antigens. To further validate this interaction, we first determined whether GST Pin 1 can depl ete M PM-2 antigens from cell Iysates. Mitotic extracts from HeLa cells were incubated with different amounts of GST-Pin1, followed by analyzing M PM -2 antigens remaining in the depl eted supernatants (Fig. 2C). At a concentration $(8 \mu \mathrm{m})$ that was $\sim 15$-fold higher than the endogenous level, Pin1 depl eted the majority of M PM-2 antigens (Fig. 2C), indicating that Pin1 strongly interacts with most M PM-2 antigens. We then determined whether endogenous Pin1 interacts with M PM-2 antigens in vivo, Pin1 was immunoprecipitated from either interphase or mitotic Hela extracts using anti-Pin1 antibodies in the presence or absence of various phosphatase inhibitors. The resulting Pin1 immunoprecipitates were probed with MPM-2. Several MPM-2 


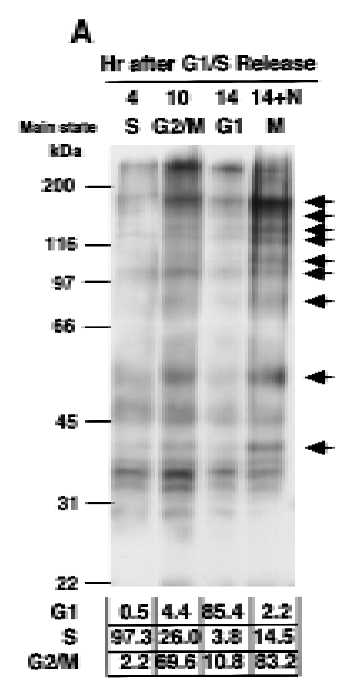

B

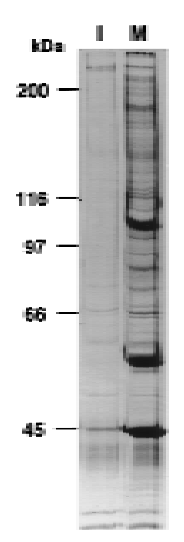

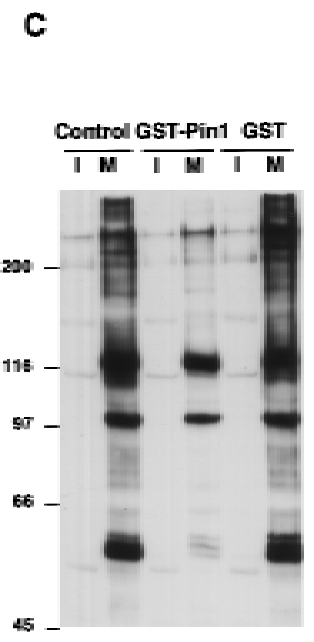

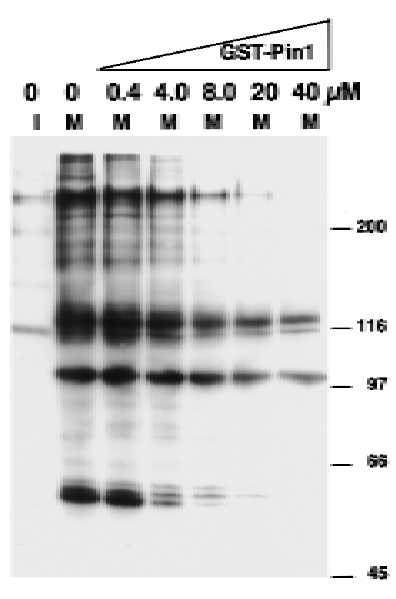

D

E

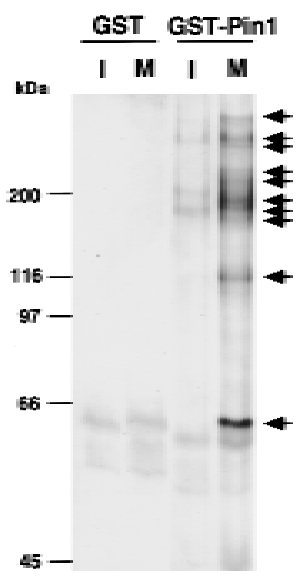

Figure 2. Pinl interacts directly with a subset of conserved mitosis-specific phosphoproteins both in vitro and in vivo. (A) Cell cycle regulation of Pin1-binding proteins. HeLa cells were harvested from different phases of the cell cycle as described in Fig. 1 and subjected to flow cytometric analysis (bottom) and Far Western analysis using GST-Pin1 as a probe. Equal loading of proteins was shown in each lane by protein staining and anti-Cdc2 immunoblotting analysis (data not shown). Arrows points to Pin1-binding proteins increased at mitosis. (B) Detection of Pin1-binding proteins. GST and GST-Pin1 were incubated with interphase (I) and mitotic (M) HeLa extracts at a final concentration of $20 \mu \mathrm{m}$ and glutathione beads were added, followed by extensive wash. GST-Pin1 precipitated proteins were separated on SDS-containing gel and stained by Coomassie blue R250. GST did not precipitate any specific Coomassie stainable proteins from either I or $M$ extracts (data not shown). (C) GST-Pin1 can deplete M PM -2 antigens. I and M HeLa cell extracts were either not depleted (Control), or incubated with GST or GST-Pinl beads. After removing the beads, the supernatants were subjected to immunoblotting analysis using M PM -2. To determine the concentration of Pin1 required to depl ete M PM -2 antigens, mitotic extracts were incubated with increasing concentrations of GSTPin1 and then GST-agarose beads were added to precipitate GST-Pin1-binding proteins. Proteins present in the depleted supernatants, together with control total interphase and mitotic extracts, were subjected to immunoblotting analysis using MPM-2. (D) Coimmunoprecipitation of

Pin1 and M PM-2 antigens. Using anti-Pin1 antibodies, Pin1 was immunoprecipitated from I and M lysates in the presence or absence of various phosphatase inhibitors, followed by immunoblotting with MPM-2. A rrows point to the M PM-2 antigens that are immunopreci pitated by Pin1 antibodies. (E) Precipitation of Xenopus M PM-2 antigens by human Pin1. Xenopus interphase (I) extracts were driven into mitosis $(\mathrm{M})$ by addition of nondegradable cycl in B. Both I and $\mathrm{M}$ extracts were incubated with agarose beads containing GST or GST-Pin1, followed by immunoblotting analysis with MPM-2 antibody. Arrows point to proteins that are specifically precipitated by GST-Pinl.

antigens were coimmunoprecipitated with anti-Pin1 anti bodies (Fig. 2D, right). However, the coimmunoprecipitation between Pin1 and the MPM-2 antigens was not detected in the absence of phosphatase inhibitors (Fig. $2 \mathrm{D}$, left). These results indicate that stable complexes between Pin1 and M PM-2 antigens exist in vivo, likely in a phosphorylation-dependent manner, and that Pin1 does not form complexes with all Pin1-binding proteins at the same time in vivo. Taken together, these results demonstrated that Pin1 interacts directly both in vitro and in vivo with a subset of mitotic phosphoproteins that overlaps with the set of proteins known as M PM-2 antigens.

Because both Pin1 and MPM-2 antigens are highly conserved, it is possible that Pin1-binding proteins are also conserved. To examine this possibility, we exam- ined the interaction between human Pin1 and mitotic phosphoproteins in Xenopus extracts. When GST-Pin1 was incubated with interphase or mitotic egg extracts, Pin1 precipitated specifically a subset of MPM-2 antigens from mitotic extracts, with molecular masses similar, although not identical, to those present in human cells (Fig. $2 \mathrm{C}, \mathrm{E}$ ). Again, this interaction between Pin1 and Xenopus M PM - 2 antigens was specific as it was not detected whether the precipitation was performed with control GST glutathione beads (Fig. 2E). Thus, the interaction between Pin1 and mitosis-specific protein is evolutionarily conserved from amphibians to mammals.

Mutations in the binding pocket abolish the ability of Pinl to interact with most mitotic phosphoproteins

The above results demonstrate that Pin1 binds directly 
Figure 3. Generation of Pin1 mutants unable to bind phosphoproteins. (A) Model for a phosphorylated Ser-Pro dipeptide bound to the active site of Pin 1 in the Syn 90 conformation. A basic cluster consisting of conserved Lys-63, Arg-68, and Arg-69 sequesters a sulfate ion in close proximity to the $\beta$-methyl group of the Ala residue in the bound Ala-Pro dipeptide. The Phospho-Ser has been modeled on the original Ala in an extended low energy conformation and in the maximal overlap of the extended Phospho-Ser side chain with the sulfate ion. Steric clashes of the Phospho-Ser side chain with the Pin 1 active site in the cis or trans conformations would necessitate an active site rearrangement, or a transition of the

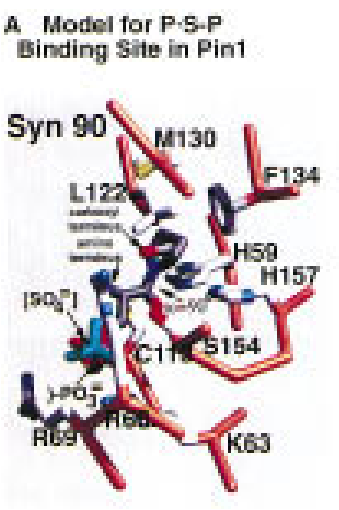

B PPlsse Assay

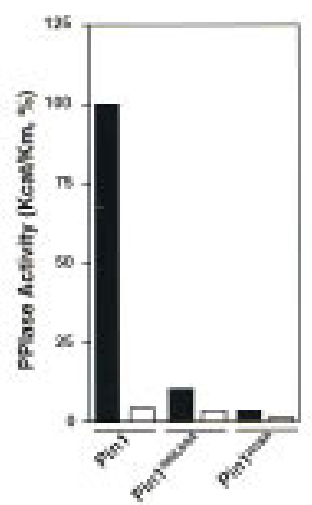

C GST-Pin1-PP, then MPM2-1日

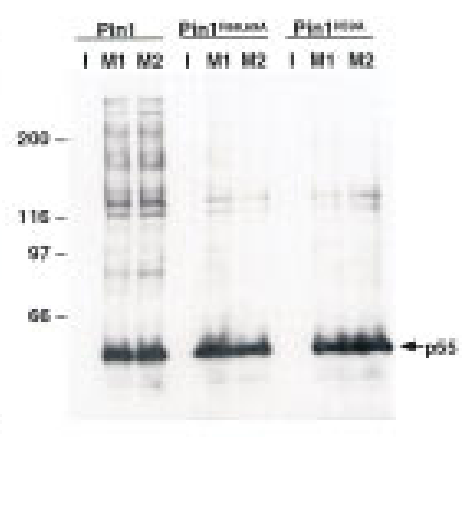
Phospho-Ser side chain to a higher energy conformation. Atoms in the active site have been color coded for clarity. Oxygen is red, nitrogen is blue, carbon is black, and sulfur is yellow. Syn 90 indicates the conformation of the Phospho-Ser-Pro peptide bond being between cis (0) and trans (180). [Reproduced, with permission, from Ranganathan et al. (1997)] (B) PPlase activity of mutant proteins. Two Pin 1 mutants were generated that contain either single Ala substitution at His-59 (Pin1 ${ }^{\mathrm{H} 59 \mathrm{~A}}$ ) or double Ala substitutions at Arg-68 and Arg-69 (Pin1 ${ }^{\text {R68,69A }}$ ), which are the amino acids implicated in binding the Pro residue or putative phosphate in the substrate, respectively, as shown in A. Both Pin1 and mutants were expressed and purified as GST fusion proteins. Purified Pin1 and the mutants were subjected to PPIase assay using two different substrates; one substrate had an Ala as the amino acid amino-terminal to the Pro (AAPF, open bars), and the second substrate has a Glu amino-terminal to the Pro (AEPF, solid bars). (C) Phosphoprotein-binding activity of mutant proteins. After incubated with I or M extracts, proteins associated with GST-Pin1, GST-Pin1 ${ }^{\text {R68,69A }}$ or GSTPin $1^{\mathrm{H} 59 \mathrm{~A}}$ beads were probed with MPM-2. $\mathrm{M} 1$ and $\mathrm{M} 2$ represent mitotic extracts prepared from two independent experiments. Although the exact intensity of M PM-2 staining in each precipitated protein varies as a result of changes in the phosphorylation state, overall patterns are quite similar in all different experiments.

numerous conserved mitotic phosphoproteins in a mitosis-dependent manner. To insure that this interaction is highly specific for Pin1, site-specific mutations were introduced into Pin1. A high resolution X-ray structural and preliminary functional analysis of Pin1 (Ranganathan et al. 1997) suggest that a basic cluster consisting of Lys-63, Arg-68, and Arg-69 could coordinate a putative phosphate group in the substrate (Fig. 3A). Ala substitutions at these residues $\left(\operatorname{Pin}^{\mathrm{R}}{ }^{68,69 \mathrm{~A}}\right.$ ) should cause a reduction in the ability to bind phosphorylated residues amino-terminal to the target Pro resi due in the substrate. In addition, His-59 has been shown to have an intimate contact with the cyclic side chain of the catalyzing Pro residue (Fig. 3A). An Ala substitution at His-59 of Pin1 $\left(P i n 1^{\mathrm{H} 59 \mathrm{~A}}\right)$ should therefore disrupt the interaction between Pin1 and the substrate Pro residue.

The mutant proteins were expressed and purified as GST fusion proteins, and both their PPlase activity and their ability to bind mitotic phosphoproteins were determined. PPlase activity was assayed with two peptide substrates: AEPF, which has an acidic residue at the position amino-terminal to the catalytic Pro residue, and AAPF, which does not. As shown previously (Ranganathan et al. 1997), Pin1 had a strong preference for the AEPF substrate (Fig. 3B). The PPlase activity of Pin1 ${ }^{\mathrm{R} 68,69 \mathrm{~A}}$ was reduced $>90 \%$ against AEPF, whereas the reduction was very small against AAPF. Moreover, Pin1 ${ }^{\mathrm{R} 68,69 A}$ had little preference for either substrate (Fig. 3B). These results confirm that residues Arg-68 and Arg69 are critical for promoting strong sel ection for a negatively charged residue at the position amino-terminal to the substrate Pro residue. The PPlase activity of Pin $1^{\mathrm{H} 59 \mathrm{~A}}$ was barely detectable against either peptide substrate, confirming the importance of His-59 in Pin1 substrate binding or catalysis (Fig. 3B).

To determine whether the Pin1 mutants interact with mitotic phosphoproteins, GST-Pin1, GST-Pin1 ${ }^{\text {R68,69A }}$, and GST-Pin $1^{\mathrm{H} 59 \mathrm{~A}}$ fusion proteins were incubated with interphase or mitotic HeLa cell extracts and associated proteins subjected to M PM-2 immunoblotting analysis. As shown in Figure $3 C$, Pinl interacted specifically with M PM-2 antigens in two independently prepared mitotic extracts, but the binding activity of both $\operatorname{Pin}^{\mathrm{R} 68,69 \mathrm{~A}}$ and Pin $1^{\mathrm{H} 59 \mathrm{~A}}$ was significantly reduced compared to the wild-type protein. A few proteins including the most strongly reacting $p 55$ band could still be recognized. The two Pin1 mutants also failed to bind most mitotic phosphoproteins from Xenopus extracts (data not shown). Thus mutating the residues that are implicated in binding either the substrate's putative phosphate group or the substrate's Pro resi due abol ish the ability of Pin1 to bind M PM -2 antigens. This suggests that the active site residues in Pinl contact both the phosphorylated Ser/Thr and the Pro residues on M PM - 2 antigens.

Identification of several mitotic regulators as Pin1 targets

Several known mitotic regulators such as cyclin B, Cdc25, Myt1, Plk1, and Cdc27 are phosphorylated at mitosis (T aagepera et al. 1993; Kuang et al. 1994; King et al. 1995; Mueller et al. 1995). To identify at least a few of 
the many Pin1-binding proteins, the proteins that bound GST -Pin1 beads were isolated from HeLa cells or Xenopus extracts and probed with antibodies specific for known mitotic phosphoproteins. As shown previously (Strausfeld et al. 1994; Kuang et al. 1994; Golsteyn et al. 1995; Hamanaka et al. 1995), level s of PIk1 and cycl in B1 increased at mitosis, whereas similar amounts of Cdc25C were present in interphase and mitotic HeLa cells. Moreover, a significant fraction of Cdc25C, PIk1, Myt1, Cdc27, and PTP-1B became hyperphosphorylated during mitosis and exhibited a shift in electrophoretic mobility by SDS-PAGE (Fig. 4A,C; data not shown). Although cyclin B1 and PTP-1B were not precipitated by Pin1 in either interphase or mitotic extracts (Table 1), Pin1 bound selectively only to the mitotically hyperphosphorylated form of Cdc25C, Plk1, Myt1, and Cdc27 (Fig. 4A). Furthermore, neither mutant Pin1 ${ }^{\text {R68,69A }}$ nor Pin1 $1^{\mathrm{H} 59 \mathrm{~A}}$ interacted with $\mathrm{Cdc} 25$ or $\mathrm{Cdc} 27$ (Fig. 4B), indicating that the residues that are implicated in binding either the substrate's putative phosphate group or the substrate's Pro residue are necessary for Pin1 to bind Cdc25 and Cdc27. Similarly, only the mitotic, but not the interphase form of Xenopus $\mathrm{Cdc} 27$ was precipitated by Pin1 (Fig. 4C). Moreover, pretreatment of the mitotic extract with calf intestine phosphatase (CIP) dephos- phorylated compl etely $\mathrm{Cdc} 27$ and abolished the interaction between Pin1 and Cdc27 (Fig. 4C), demonstrating a phosphorylation-dependent interaction. These results indicate that the interaction between Pin1 and Cdc25 or Cdc27 is likely to be mediated by a phosphorylated Ser/ Thr-Pro motif.

To gain a sense of the generality of the interaction between Pinl and mitotic phosphoproteins and to confirm the Pin1 interaction with target proteins is indeed mediated by phosphorylation, we examined the ability of Pinl to bind other known mitotic phosphoproteins and a set of mitotic phosphoproteins identified by a systematic phosphoprotein screen (Stukenberg et al. 1997). Proteins synthesized in vitro were phosphorylated in a cell cyclespecific manner by incubating them in either Xenopus interphase or mitotic extracts. These labeled protein were incubated subsequently with GST-Pin1 beads, extensively washed and the bound proteins analyzed by SDS-PAGE (Fig. 4D). To validate this method, Cdc25 was first tested. Again, the mitotically phosphorylated form of in vitro translated Cdc25 could be precipitated by GST-Pin1 beads. However, C dc25 was not recognized by Pin1 if it was incubated in interphase extracts. M oreover, Pin1 did not interact with Cdc25 if the mitotically phosphorylated Cdc25 was treated with phosphatase be
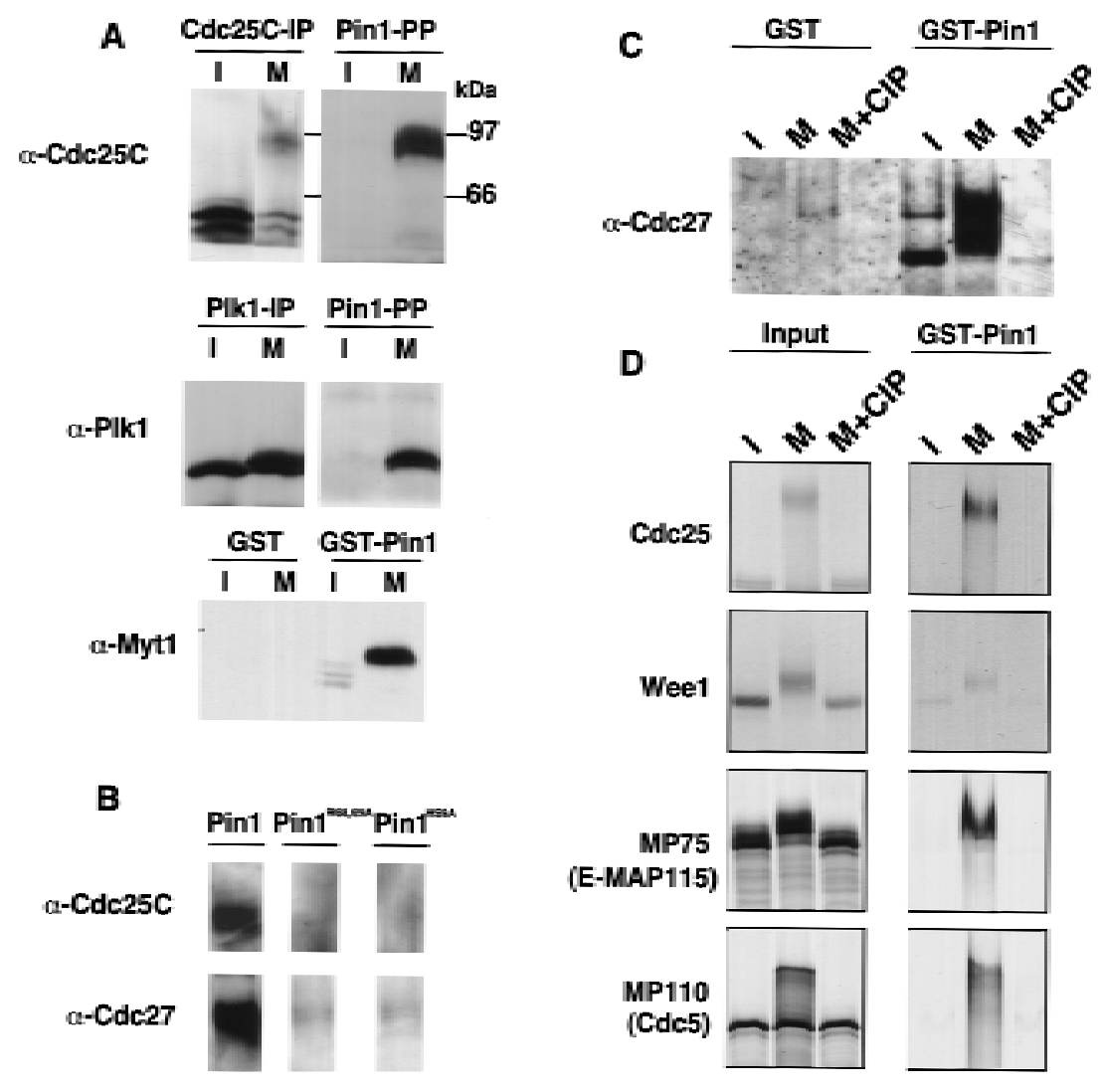

Figure 4. Pinl can interact with important mitotic regulators in mitosis-specific and phosphorylation-dependent manner. (A) Binding of Pin1 to human Cdc25C, PIk1, and $M y t 1$. Similar amounts of proteins from I and M HeLa cells were either immunoprecipitated (IP) and immunoblotted using the same anti-Cdc25C or anti-Plk1 antibodies, or subjected to GST bead pulldown assay (Pin1-PP, GST, GST-Pin1), followed by immunoblotting analysis using anti-Cdc25C, anti-PIk1, or anti-M yt1 antibodies. (B) Failure of the Pin1 mutants to bind Cdc25C and Cdc27. GSTglutathione beads containing wild-type and mutant Pin1 proteins were incubated with mitotic extracts and proteins associated with the beads were subjected to immunoblotting analysis using anti-Cdc25C and anti-Cdc27 antibodies. (C) Interaction between Pin1 and Xenopus Cdc27. Xenopus interphase (I) extracts were driven into mitosis $(M)$ and half of the reaction was treated subsequently with calf intestine phosphatase $(M+C I P)$. These three different extracts were incubated with agarose beads containing GST or GST-Pin1, followed by immunoblotting analysis with anti-Cdc27 antibodies. (D) Interaction between Pin1 and other selected mitotic phosphoproteins. The indicated proteins were synthesized by in vitro transcription and transla-

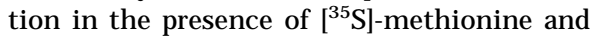
incubated with Xenopus I, M, or M +CIP. These proteins were separated on SDS-containing gels either directly (input) or first precipitated by GST-Pin1 beads (GST-Pin1). 
Table 1. Interaction between Pinl and selected mitotic phosphoproteins

\begin{tabular}{lcc} 
Phosphoproteins $^{\mathrm{a}}$ & Interphase $^{\mathrm{b}}$ & Mitotic $^{\mathrm{b}}$ \\
\hline Cdc25* $^{*}$ & - & ++ \\
PIk1* & - & ++ \\
PIx1 & - & ++ \\
Wee1 & + & ++ \\
Myt1* & - & ++ \\
Mos & + & ++ \\
Cdc27* & - & ++ \\
NIMA & - & ++ \\
Sox3 & - & ++ \\
Xbr-1b & - & ++ \\
MP75 (E-MAP-115) & - & ++ \\
MP110 (Cdc5) & - & ++ \\
MP68 & - & ++ \\
MP30 & - & ++ \\
MP105 & + & - \\
MP48 & - & - \\
Cyclin B* & - & - \\
PTP-1B* & - & + \\
\hline Thebindingbetwen Pin1 & \\
\hline
\end{tabular}

The binding between Pinl and all selected mitotic phosphoproteins was assayed by incubating synthesized proteins with interphase and mitotic Xenopus extracts, followed by precipitation with GST-Pin1 beads.

aThe Pin1 interactions with those proteins indicated with an asterisk $(*)$ were also confirmed by GST-Pin1 pulldown assay from endogenous interphase and mitotic HeLa cell extracts. ${ }^{b}(+)$ A weak, but above background, interaction; (+t) readily detectable interaction; (++) strong interaction.

fore the GST-Pin1 incubation (Fig. 4D, GST-Pin1). These results demonstrate that this method can be used to detect mitosis-specific and phosphorylation-dependent interactions between Pin1 and phosphoproteins. Of the 13 mitotic phosphoproteins examined, Pin1 bound 10 in a mitosis and phosphorylation-dependent manner (summarized in Table 1), including Weel, MP75, and MP110, as shown in Figure 4D. MP75 and MP110 are Xenopus proteins related to the microtubule-associated protein E-MAP-115 and the fission yeast $\mathrm{G}_{2}$ transcription factor $\mathrm{Cdc5}$, respectively. These results indicate that Pin1 may target many but not all mitosis-specific phosphoproteins.

Pin1, but not the mutants, blocks cell cycle progression in Xenopus embryos and entry into mitosis in Xenopus extracts

The above results establish a specific interaction between Pin1 and mitosis-specific phosphoproteins. To demonstrate that this binding is biologically important for Pinl function, we turned to the experimentally amenable Xenopus system. Because Pin1 is conserved from yeast to humans, it is likely that Pin1 exists in Xenopus. To confirm this, Xenopus egg extracts were immunoblotted with two separate anti-human Pin1 antisera. Both antibodies, but not their respective preimmune sera, specifical ly recognized a band that comigrated with human Pin1 at $18 \mathrm{kD}$ (data not shown), indicating that Pinl is present in Xenopus.

Overexpression of Pin1 has been shown to inhibit cell cycle progression in both yeast and HeLa cells (Hanes et al. 1989; Lu et al. 1996). To examine whether increasing the concentration of Pin1 has similar biological effects in Xenopus, we injected Pin1 or Pin1 mutants into one cell of two-cell stage embryos and allowed the embryos to develop for $3 \mathrm{hr}$ (about five divisions). Wild-type Pin1injected cells failed to cleave or cleaved slowly when compared to the cells in the uninjected side (Fig. 5A). A similar concentration ( $4 \mu \mathrm{m}$ final) of either Pin1 mutant had little effect on the cell cycle (Fig. 5A). In a separate experiment Pin1 bl ocked cleavage of the injected cells in a concentration-dependent manner, and at a concentration 20-fold above the estimated endogenous levels (10 $\mu \mathrm{M}$ ), completely inhibited the cell cycle (Fig. 5B). In contrast, higher concentrations of the mutant proteins were needed to bl ock the cell cycle (Fig. 5B). Injection of control BSA had no obvious effect on cell cycle progression (data not shown). These results suggest that Pin1 must bind mitotic phosphoproteins to bl ock cell cycl e progression.

To determinethe nature of the cl eavage bl ock in Xeno-

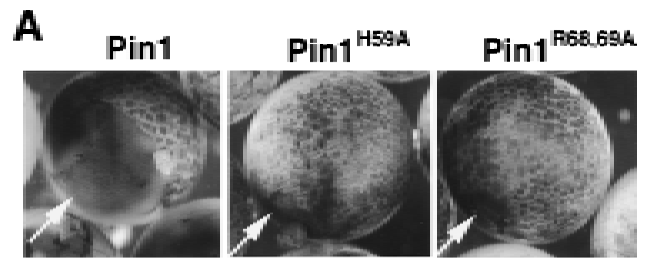

B

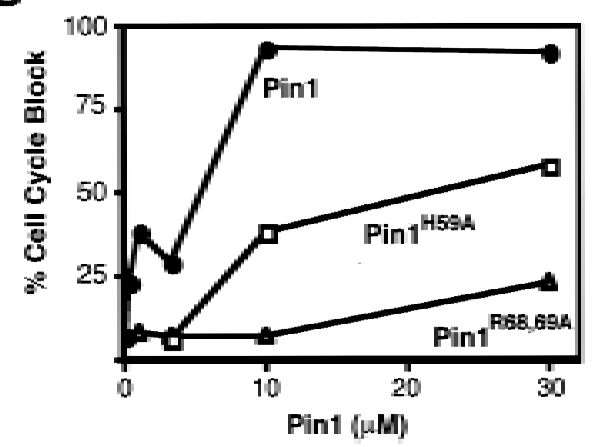

Figure 5. Microinjection of Pin1 protein, but not its mutants, inhibits mitotic division in Xenopus embryos. (A) GST fusion proteins containing wild-type Pin1 or its two mutants were microinjected to into one blastomere of Xenopus embryos at the two-cell stage. The injected embryos were al lowed to devel op at $18^{\circ} \mathrm{C}$ for $3 \mathrm{hr}$ (about five cycles) followed by photography of typical embryos. Embryos with a cell cycle arrest had fewer and larger blastomeres on one side. The arrows point to the injected blastomere. (B) GST-Pin1 and the mutants were titrated into the assay described in A except that the embryos were injected at the four-cell stage. The percentage of embryos with a cell cycle block phenotype at each Pinl concentration was determined and presented graphically. 
pus, GST-Pin1 was added to Xenopus egg extracts that had been arrested in second meiotic metaphase because of the activity of the cytostatic factor. These extracts are arrested in mitosis (meiosis II) and reenter the cell cycle in response to the addition of $\mathrm{Ca}^{2+}$. Extracts containing demembranated sperm to monitor nuclear morphology and rhodamine-tubulin to monitor microtubule spindle assembly, were activated with $\mathrm{Ca}^{2+}$. Pin1 was added after the extracts had entered interphase (15 min after the addition of $\left.\mathrm{Ca}^{2+}\right)$, and the subsequent entry of the extracts into mitosis was followed by nuclear morphology and $\mathrm{Cdc} 2$ kinase acti vity using histone $\mathrm{H} 1$ as a substrate. Addition of either 10 or $40 \mu \mathrm{M}$ Pin1, 20- or 80 -fold higher than endogenous levels, completely blocked entry into mitosis as detected by the persistence of interphase nuclei and low Cdc2 kinase activity (Fig. 6A,B). In contrast, the same extracts containing $40 \mu \mathrm{m}$ of either BSA or the mutant Pin1 proteins entered mitosis by $70-80$ min as detected by nuclear envel ope breakdown, spindle formation and high histone $\mathrm{Hl}$ kinase activity (Fig. 6A,B). Thus, as shown previously in HeLa cells (Lu et al. 1996), increasing the Pinl concentration causes a cell cycle block in $\mathrm{G}_{2}$. More important, Pin1 must bind mitotic phosphoproteins to elicit this phenotype.

Pin1 binds and inhibits mitotically phosphorylated Cdc25

The above results indicate that overexpression of Pin1 inhibits mitotic entry in Xenopus, as is the case in HeLa cells and yeast (Lu et al. 1996). Entry into mitosis is regulated by dephosphorylation of $\mathrm{Cdc} 2$ by the phosphatase $\mathrm{Cdc} 25$, and $\mathrm{Cdc} 25$ is activated by mitosis-specific phosphorylation at the MPM-2 epitope at the $G_{2} /$ M transition (Russell and N urse 1986; Kuang et al. 1994; Strausfeld et al. 1994). Earlier results indicated that it is the mitotically phosphorylated form of Cdc25 that interacts with Pin1 in vitro (see Fig. 4). Therefore, it is concei vable that the inhibitory effects of Pin1 on entry into mitosis could at least partially explained through inhibition of Cdc25 activity.

To test this possibility, we first examined whether Pin1 interacts with Cdc25 in vivo and if so, whether this interaction is cell cycle regulated. Xenopus eggs were collected at various times after fertilization and subjected to immunoprecipitation using anti-Xenopus $\mathrm{Cdc} 25$ antibodies as well as histone $\mathrm{H} 1$ kinase assay to monitor cell cycle progression. When the resulting Cdc25 immunoprecipitates were immunoblotted with anti-Pin1 antibodies, we found that endogenous Pin1 was preci pitated by anti-C dc25 antibodies (Fig. 7A). Furthermore, this interaction between Pin1 and Cdc25 was cell cycle regulated, significantly increased just before mitosis (Fig. 7A). Similar results were also obtained using synchronized HeLa cells using anti-human Cdc25C (data not shown). Unfortunately, we were not able to detect $\mathrm{Cdc} 25$ in anti-Pin1 immunoprecipitates, probably because the amount of $\mathrm{Cdc} 25$ precipitated is below the detection of the $\mathrm{Cdc} 25$ antibodies. It is worth pointing out that the percentage of coimmunopreci pitatable Pin1

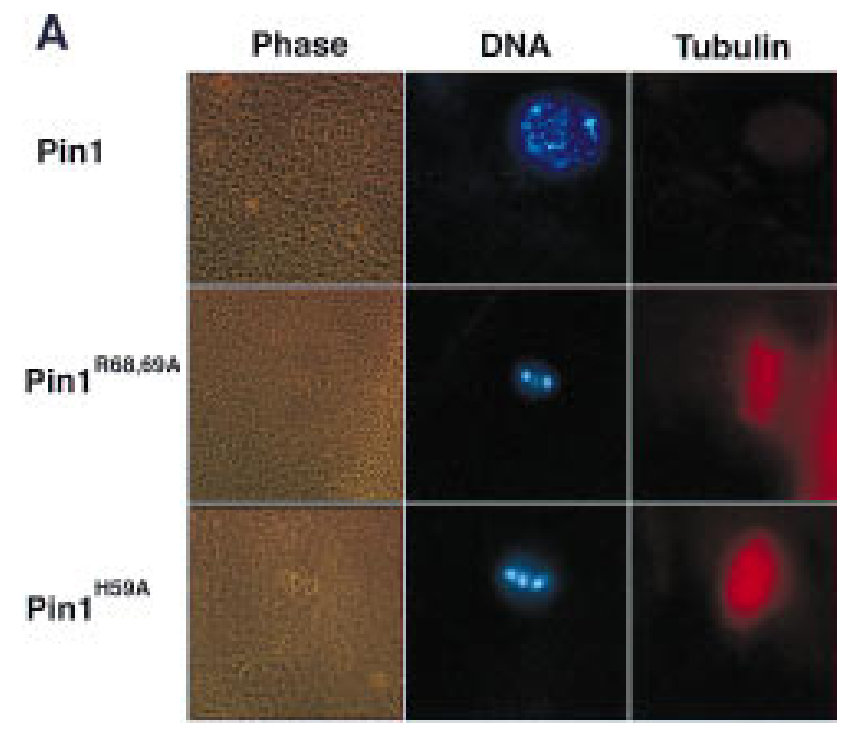

B

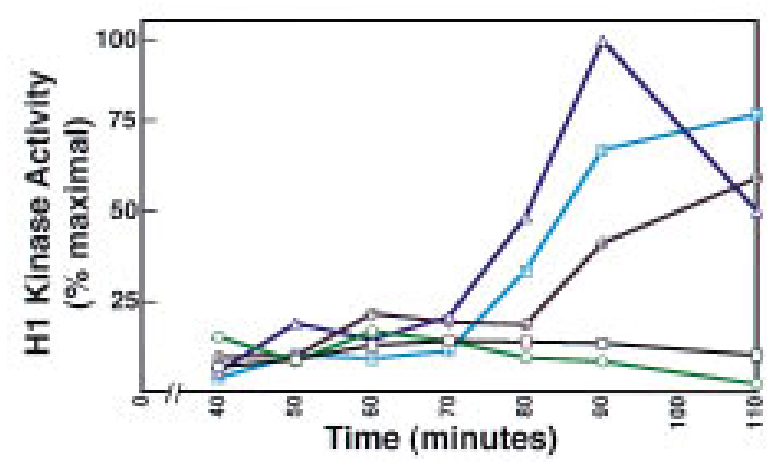

Figure 6. Pin1, but not the mutants, blocks mitotic entry in Xenopus extracts. (A) Xenopus cytostatic factor (CSF)-arrested extracts containing demembranated sperm and rhodamine-tubulin were activated with $0.4 \mathrm{~mm} \mathrm{Ca}{ }^{2+}$ at time zero, and $15 \mathrm{~min}$ later, Pinl or the mutants was added to $40 \mu \mathrm{m}$ and at $110 \mathrm{~min}$ the nuclear morphology was examined microscopical ly. (B) The activity of $\mathrm{Cdc} 2$ was foll owed using histone $\mathrm{H} 1$ as a substrate in the CSF extract experiment described in A; $40 \mu \mathrm{m}$ GST-Pin1 (black squares), $40 \mu \mathrm{M}$ GST-Pin1 ${ }^{\mathrm{R} 68,69 \mathrm{~A}}$ (dark blue triangles), and $40 \mu \mathrm{M}$ GST-Pin ${ }^{\mathrm{H} 59 \mathrm{~A}}$ (brown crossed circles). Also shown are reactions in the same extracts that contained $10 \mu \mathrm{M}$ GSTPin1 (green circles) and $40 \mu \mathrm{m}$ BSA (light blue crossed squares).

and phosphorylated $\mathrm{Cdc} 25$ is not high. This might be expected because the complex might not be stable to the stringent immunoprecipitation conditions, the amount of Cdc25 phosphorylated on Pin1-binding sites might be low at this point, or the complex might have a high off rate as the phosphorylated Cdc25 is a substrate of Pin1. N evertheless, these results suggest that Pin1 is associated with $\mathrm{Cdc} 25$ at a time when $\mathrm{Cdc} 25$ is partially phosphorylated and yet its activity is low (Izumi et al. 1992; Lee et al. 1994).

Because the interaction between Pin1 and Cdc25 is 
A
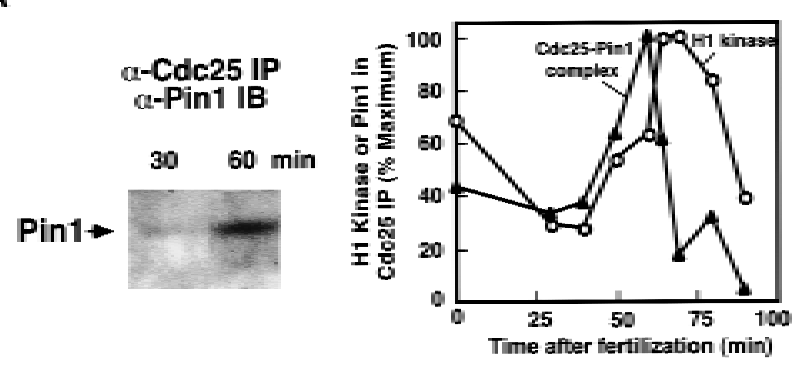

B
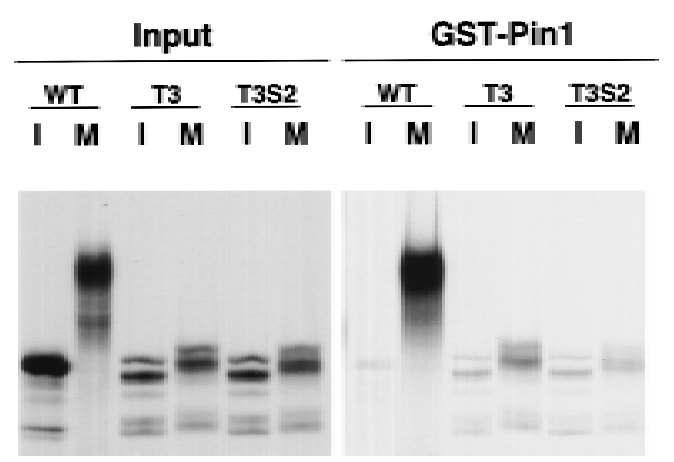

Figure 7. Cell cycle-regulated in vivo association of Pinl and C dc25 and the effect of mutating Cdc25 phosphorylation sites on the interaction. (A) Cell cycle-dependent interaction between Pin1 and Cdc25. Xenopus eggs were fertilized and assayed for both $\mathrm{H} 1$ kinase activity and the Pin $1 \mathrm{Cdc} 25$ complex at the indicated times after fertilization. After crushing into a buffer containing $1 \mu \mathrm{m}$ okadeic acid, al iquots of soluble extracts were used to assay histone $\mathrm{H} 1$ kinase activity to monitor cell cycle progression $(O)$, and the remaining extracts were immunoprecipitated with anti-Cdc25 antibodies. The resulting immunoprecipitates were subjected to immunobl otting with antiPin1 antibodies ( $\mathbf{\Lambda}$ ). (Left) Pin1 coimmunoprecipitated by antiCdc25 antibodies at the two time points (30 and $60 \mathrm{~min}$ ); (right) relative $\mathrm{H} 1$ kinase activity and relative amount of Pin 1 that was immunoprecipitated by anti-C dc 25 during the first embryonic cell cycle, with either the maximal amount of Pin1 precipitated or $\mathrm{H} 1$ kinase activity being defined as $100 \%$. (B) Failure of Cdc25 mutants to bind Pin1. Wild-type Xenopus Cdc25 (WT), T3 mutant Cdc25 (T 48A, T67A, and T 138A), and T3S2 mutant Cdc25 (T 48A, T67A, T 138A, S205A, and S285A) were synthesized by in vitro transcription and translation in the presence of $\left[{ }^{35} \mathrm{~S}\right]-$ methionine and incubated with Xenopus I and M extracts. These proteins were separated on SDS-containing gels either directly (input) or first precipitated by GST-Pin1 beads (GSTPin1).

mediated by phosphorylation of Cdc25 (Fig. 4D), we then examined whether Pin 1 interacts with Cdc 25 on important phosphorylation sites. At entry into mitosis, Cdc25 is phosphorylated at multiple Thr/Ser-Pro sites (Izumi and M al ler 1993; Ogg 1994; Kumagai and Dunphy 1996). Izumi and Maller (1993) have shown that the triple mutation of conserved Thr-48, Thr-67, and Thr-138 (T3 Cdc25), and the quintupl e mutation of the three Thr residues plus Ser-205 and Ser-285 (T3S2 Cdc25) prevent most of the shift in electrophoretic mobility of Cdc25 after incubation with mitotic extracts. When they mea- sured the ability of the $\mathrm{Cdc} 25$ mutants to activate $\mathrm{Cdc} 2$ in the Cdc25-depleted oocyte extracts and to initiate mitotic entry in oocyte extracts, the activities of T3 and T 3S2 mutants were reduced $~ 70 \%$ and $90 \%$, respectively (Izumi and Maller 1993). These results indicate that these $\mathrm{Thr} / \mathrm{Ser}$ residues are essential for the Cdc25 function. We examined the ability of Pin1 to bind the T3 and T3S2 Cdc25 mutants. As shown previously (Izumi and Maller 1993), the T3 and T3S2 C dc25 mutants failed to undergo the mobility shift after incubation with mitotic extracts (Fig. 7B, right). Although Pin1 strongly bound the mitotically phosphorylated form of Cdc25, Pin1 almost (T3) or completely (T3S2) failed to bind the Cdc25 mutants, which were incubated with either interphase or mitotic extracts (Fig. 7B, left). Although further experiments are required to pinpoint which phosphorylation sites play the major role in mediating the Pin1 and Cdc25 interaction, these results show that Pin1 interacts with the phosphorylation sites on Cdc25 that are essential for its mitotic activation.

The above results indicate that Pin1 interacts with Cdc25 both in vitro and in vivo. Therefore, we tested whether Pin1 could affect the physiological activity of Cdc25, which is to dephosphorylate and activate the cyclin $\mathrm{B} / \mathrm{Cdc} 2$ complex. To generate the mitotically phosphorylated form of Cdc25, GST-Cdc25 was incubated in Xenopus mitotic extracts, affinity purified on glutathione-agarose beads and eluted. This mitotic $\mathrm{Cdc} 25$ was at least ninefold more active than GST-Cdc25 purified in parallel from interphase extracts (data not shown). This mitotic GST-C dc25 activated the cyclin B/Cdc2 complex, which was kept inactive as a result of inhibitory phosphorylations on Tyr-15 and Thr-14 (Fig. 8A). However, if Pin1 was included in the assay, mitotic Cdc25 failed to activate the Cdc2 complex (Fig. 8). In contrast, neither the mutant Pin $1^{\mathrm{R} 68,69 \mathrm{~A}}$ at the same concentration, nor BSA at a 25-fold higher concentration had a significant inhibitory effect on Cdc25 activity (Fig. 8A). Fivefold higher concentrations of Pin1 ${ }^{\text {R68,69A }}$ could inhibit mitotic Cdc25 activity partially (Fig. 8B), a result that is consistent with the requirement for higher concentrations of this mutant protein to arrest the Xenopus cell cycle (see Fig. 5 and 6). To rule out the possibility that Pin1 could directly inhibit the cyclin B/Cdc2 complex itself, we examined the effect of Pinl and its mutants on the activity of dephosphorylated-active cyclin $\mathrm{B} / \mathrm{Cdc} 2$ under same conditions. Neither Pin1 nor the Pin1 mutant had any effect on Cdc2 activity (Fig. 8C). Taken together, these results indicate that Pinl could inhibit premature mitotic activation of $\mathrm{Cdc} 25$ by interacting with the phosphorylation sites on Cdc25 that are essential for its activation. This offers one explanation for the ability of Pin1 to inhibit mitotic entry.

\section{Discussion}

We have demonstrated and characterized a cell cyclespecific and phosphorylation-dependent interaction between the PPlase Pinl and phosphoproteins. Pinl binds to a subset of mitosis-specific phosphoproteins, includ- 
A

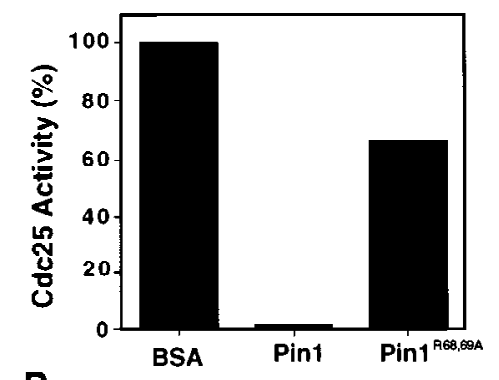

B
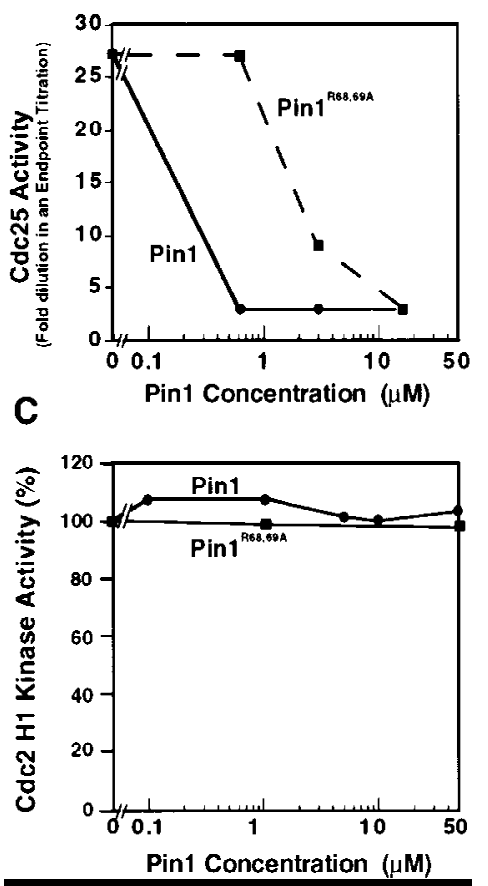

Figure 8. Pin1, but not the mutant, directly inhibits the ability

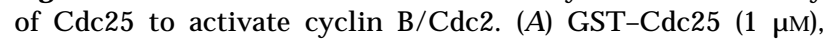
which had been incubated in Xenopus mitotic extracts and purified on glutathione-agarose, was incubated with $0.62 \mu \mathrm{m}$ of BSA, GST-Pin1, or GST-Pin $1^{\mathrm{R} 68,69 \mathrm{~A}}$. The resulting reaction was incubated for $10 \mathrm{~min}$ with beads containing GST-cyclin B/C dc2 phosphorylated on the inhibitory residues of Cdc2 (Thr-14, Tyr15). The beads were washed and the activity of cyclin $B / C$ dc2 was assayed using histone $\mathrm{HI}$ as a substrate. (B) Titration of

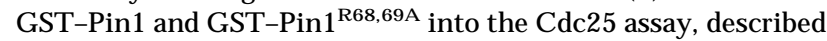
in $A$ and in Materials and M ethods. (C) Effect of Pin1 on Cdc2 kinase activity. Different concentrations of Pin1 and its mutant protein were added to active cyclin B/Cdc2 complex, followed by assaying $\mathrm{H} 1$ kinase activity using the same conditions as described in $A$ and $B$.

ing many MPM-2 antigens, in both human cells and in Xenopus extracts; this interaction is direct and depends on the phosphorylation of the Pin1-binding proteins. A limited number of these Pin1-binding proteins have been identified and include Cdc25, PIk1, Weel, Myt1, Mos, $\mathrm{Cdc} 27$, and proteins with sequence similarity to E-M AP115 and the fission yeast $\mathrm{Cdc} 5$. In Xenopus, introduction of Pinl inhibits mitotic division in embryos, and pre- vents activation of $\mathrm{Cdc} 25$ and $\mathrm{Cdc} 2$ and entry into mitosis in extracts. Furthermore, just before mitosis, Pin1 not only binds directly the mitotically active form of Cdc25 through the activating phosphorylation sites, but also inhibits its activity. Significantly, these phenotypic and biochemical changes induced by Pin 1 are abolished by point mutations in the active site residues of Pin1 that are implicated in binding either the substrate Pro residue or its preceding phosphorylated Ser/Thr phosphate in the substrate. This demonstrates that the ability to bind mitotic phosphoproteins is required for its biological activity. Together with other findings that Pin1 is a phosphorylation-dependent PPIase that is specific for phosphorylated Ser/Thr-Pro peptide bond in mitotic phosphoproteins (Y affe et al. 1997), Pin1 adds potentially an additional level of mitotic regulation using a novel mechanism involving sequence-specific and phosphorylation-dependent proline isomerization.

\section{The relationship between Pin1 and MPM-2 antigens}

In 1983, Davis et al. used total mitotic extracts from HeLa cells as antigens and generated a monoclonal antibody, M PM -2, that specifically recognized phosphoproteins from mitotic cells, but not from interphase cells. This puzzling and remarkable specificity has been seen in all eukaryotic organisms so far examined (Davis et al. 1983; Vandre et al. 1984; Hecht et al. 1987; Keryer et al. 1987; Wordeman et al. 1989). M PM-2 appears to recognize a conserved phosphoepitope that contains the motif phosphorylated Ser/Thr-Pro, on at least 50 mitotic phosphoproteins (Davis et al. 1983; Vandre et al. 1986; Westendorf et al. 1994; Matsumoto-Taniura et al. 1996). However, the importance of the MPM-2 epitope on mitotic phosphoproteins has remained mysterious.

Whereas MPM-2 is a monoclonal antibody, Pin1 is a highly conserved endogenous enzyme. Yet, there are strong similarities between the interaction of Pin1 and M PM-2 with their respective targets. First, they both recognize an overlapping subset of conserved mitosis-specific phosphoproteins and they both localize to the nuclear speckle during interphase and to mitotic chromosomes at mitosis (Davis et al. 1983; Vandre et al. 1986; Hirano and Mitchison 1991; Kuang et al. 1994; Westendorf et al. 1994; Lu et al. 1996; Matsumoto-Taniura et al. 1996; this study). Second, the interaction either between Pin1 and its interacting proteins or M PM-2 and its antigens is dependent on mitosis-specific phosphorylation of the target proteins (Davis et al. 1983; Westendorf et al. 1994; this study). Third, both inhibit cell cycle progression in Xenopus embryos and entry into mitosis in Xenopus extracts (this study, Davis et al. 1989; Kuang et al. 1989). Fourth, Pin1 is highly conserved in all eukaryotic cells so far examined, including plants, yeast, Aspergillus, and vertebrates, as is the case for the MPM-2 epitope (Davis et al. 1983; Vandre et al. 1986; Hirano and Mitchison 1991; Kuang et al. 1994; Westendorf et al. 1994; Ye et al. 1995; M atsumoto-Taniura et al. 1996). Finally, peptide-binding specificities of Pinl and M PM-2 are al most identical, and both strongly 
bind peptides contai ning phosphorylated Ser-Pro flanked by hydrophobic residues or Arg, as shown by screening oriented degenerate peptide libraries (Yaffe et al. 1997). The observations that the antibody and Pin1 recognize the same proteins and almost the same primary sequences, as well as have similar phenotypes, indicate that the conservation of the MPM-2 epitope can be explained by the recognition of this epitope by a highly conserved mitotic regulator, Pin1.

\section{Pin1 regulation of mitotic entry}

Although the $G_{2}$ arrest phenotype is induced by overexpression of Pin1, there is enough genetic and biochemical evidence to suggest that Pin1 is working as an inhibitor of premature entry into mitosis. First, Pin1 was isolated originally as a protein that suppresses premature mitotic entry induced by the NIMA kinase in a genetic screen, indicating that Pinl has the ability to prevent premature entry into mitosis (Lu et al. 1996). Second, depletion of Pin1 from HeLa cells or Pin1 homolog Ess1 from yeast induces mitotic arrest and nuclear fragmentation. Phenotypic analysis reveals that these mitotically arrested HeLa cells are very similar to premature mitotic entry induced by overexpression of NIM A or activated Cdc2 mutant (Krek and Nigg 1991; Lu and Hunter 1995; Lu et al. 1996). These results suggest that depletion of Pin1 may actually induce premature entry into mitosis and mitotic catastrophe. Third, overexpression of Pin1 inhibits entry into mitosis in two completely different genetic systems, Xenopus, and humans (this study; Lu et al. 1996). Fourth, we have shown here that Pin1 interacts specifically with many important regulators of $\mathrm{Cdc} 2$, whose activation is shown to trigger entry into mitosis. Finally, we havealso shown that Pin1 binds a key mitotic inducer Cdc25. This interaction occurs highest just before mitosis, is mediated by the phosphorylation sites on Cdc25 that are essential for mitotic activation, and results in an inhibition of Cdc 25 activity to interphase levels. These results consistently suggest that Pinl acts as an inhibitor of the mitotic activity in $\mathrm{G}_{2}$, preventing lethal premature entry into mitosis (Johnson and Rao 1970).

Is Pin1 a general regulator of mitosis-specific phosphoproteins?

Phosphorylation is a common mechanism to regulate interactions between proteins. For example, the $\mathrm{SH} 2$ domain and the 14-3-3 protein have been shown to mediate protein-protein interactions by recognizing phosphorylated Tyr and phosphorylated Ser/Thr motifs, respectively (Pawson 1995; M uslin et al. 1996). In contrast to other phosphoprotein-binding proteins, Pin1 is the first to bind and regulate mitosis-specific phosphoproteins and is also the first to have an intrinsic prolyl isomerase activity. Interestingly, we have also found that phosphorylation of Ser/Thr-Pro, but not Tyr-Pro sequences, renders pepti des resi stant to the i somerase action of both cyclophilins and FKBPs, suggesting the need for a differ- ent enzyme to catalyze this reaction (Y affe et al. 1997). Significantly, the novel PPIase Pin1 preferentially isomerizes Pro resides preceded by phosphorylated Ser or Thr with 1300-fold selectivity compared to unphosphorylated peptides (Yaffe et al. 1997). Therefore, Pin1 is a phosphorylation-dependent PPIase that is specific for the phosphorylated Ser/Thr-Pro moieties present in mitotic phosphoproteins. These results suggest a new two-step mechanism for mitotic regulation. The first event is phosphorylation at specific Ser-Pro or Thr-Pro sites by the mitosis-specific activation of Ser/Thr kinases, creating binding sites for Pin1. Second, Pin1 binds the phosphorylated Ser/Thr-Pro motifs and induces local conformational changes through prolyl isomerization. These local conformational changes can alter the activity of a phosphoprotein, as shown previously for N IMA (Lu et al. 1996) and here for Cdc25. In addition, Pin1 could also regulate the ability of its target proteins to interact with other proteins or to be degraded.

Why the cell would use an additional regulator for proteins that have been al ready regulated by phosphorylation? As mentioned above, Pin1 may act as a inhibitor of mitotic entry in interphase to prevent premature mitotic entry. During mitosis, by acting as a general modulator of mitotic phosphoproteins, Pin1 may provide a means for temporally synchronizing or amplifying the activity of mitotic proteins. For example, the first protein to be phosphorylated by mitotic kinases may be kept inactive by direct binding to Pin1. Only after sufficient levels of mitotic phosphoproteins have been accumulated, would Pin1 inhibition be relieved simultaneously on target proteins. This would relieve inhibition of mitotic phosphoproteins and allow an abrupt wave of signaling to proceed in a synchronous manner. Alternatively, Pin1 might sequentially form complexes with different phosphoproteins whose concentration or affinity for Pin1 may change during mitosis. In this manner, Pin1 could regulate the activities of different proteins at distinct times during mitosis. Interestingly, a similar model has been shown to regulate the function of the $\mathrm{Cdk}$ inhibitor p27, which forms sequentially a complex with cyclin $\mathrm{D} / \mathrm{Cdk} 4$ and cyclin A/Cdk2 during progression through $\mathrm{G}_{1}$ and $\mathrm{S}$ (Poon et al. 1995; Reynisdottir and M assague 1997). How Pinl exerts its functions during mitotic progression are questions for future study.

\section{Materials and methods}

Expression, purification, and kinetic analysis of recombinant Pin1 proteins

Pin1 was expressed and purified by $\mathrm{Ni}^{2+}-\mathrm{NTA}$ agarose column as an amino-terminally $\mathrm{His}_{6}$-tagged fusion protein, followed by removing the tag using thrombin, as described (Lu et al. 1996; Ranganathan et al. 1997). To generate an amino-terminally GST-Pin1 fusion protein, Pin1 CDNA was subcloned into a pGEX vector and the resulting fusion protein was expressed and purified by glutathione-agarose column, as described (Lu et al. 1993, 1996). GST -Pin 1 was stored in the agarose bead at $4^{\circ} \mathrm{C}$ for 2 weeks or el uted from the beads and concentrated to $20 \mathrm{mg} / \mathrm{ml}$ with a Centricon-10 (Amicon), followed by storing at $-80^{\circ} \mathrm{C}$. 
Both preparations were stored in a buffer containing $20 \mathrm{~mm}$ HEPES (pH 7.5), $50 \mathrm{~mm} \mathrm{NaCl}$, and $1 \mathrm{~mm}$ DTT, as described (Ranganathan et al. 1997). All proteins were quantified by the method of Bradford (Bio-Rad) using BSA as a standard.

Site-directed mutations of Pin1 were introduced using PCRbased techniques and verified by DNA sequencing. The corresponding mutant proteins were expressed and purified using the same procedures as those described for wild-type Pin1. PPlase activity was measured, as described previously (Lu et al. 1996), with the exception that the absorbance of p-nitroaniline (at 395 $\mathrm{nm}$ ) was followed every second for 2-10 $\mathrm{min}$. and data were analyzed offline using a kinetic computer program written by G. Tucker-Kellogg (C. Walsh laboratory at Harvard Medical School).

\section{Analysis of Pinl and its binding proteins during cell cycle}

HeLa cells were arrested at the $G_{1} / S$ boundary using double thymidine and aphidicolin block, and released to enter the cell cycle, as described (Heintz et al. 1983; Lu and Hunter 1995). To accumulate cells at mitosis, nocodazole $(50 \mathrm{ng} / \mathrm{ml})$ was added to cells at $8 \mathrm{hr}$ after the rel ease for the time indicated in text. To obtain a large quantity of interphase and mitotic cells, HeLa cells were incubated with double thymidine and aphidicolin or nocodazole for $16 \mathrm{hr}$, which resulted in $>90 \%$ of cells being arrested at the $G_{1} / S$ boundary or mitosis, respectively. Cells were harvested and a aliquot of cells was subjected to flow cytometry analysis, as described (Lu and Hunter 1995). The remaining cells were lysed in RIPA buffer [ $10 \mathrm{~mm}$ sodium phosphate (pH 7.4), $150 \mathrm{~mm} \mathrm{NaCl}, 1 \% \mathrm{NP}-40,1 \%$ sodium deoxycholate, $0.1 \%$ SDS, $50 \mathrm{~mm} \mathrm{NaF}, 1 \mathrm{~mm}$ sodium orthovanadate, 10 $\mu \mathrm{g} / \mathrm{ml}$ of aprotinin, $50 \mu \mathrm{g} / \mathrm{ml}$ of PMSF, and $1 \mathrm{~mm} \mathrm{DTT}$ ] and the same amount of total proteins was subjected to immunoblotting analysis using various antibodies for Far Western analysis using GST-Pin1 as a probe. For Far Western analysis, after blocking with $5 \%$ BSA, membranes were incubated with $2 \mu \mathrm{g} /$ $\mathrm{ml}$ of GST-Pinl in TBST for $2 \mathrm{hr}$, followed by incubation with anti-GST monoclonal antibodies (UBI) and the ECL detection procedures.

\section{Microinjection of Xenopus embryos}

Unfertilized eggs were incubated with sperm, dejellied, and 4 $\mu \mathrm{M}$ of the indicated protein ( 10 -fold above the estimated endogenous levels) was injected in one cell of two-cell stage embryos (30 embryos each protein). The injected embryos were allowed to devel op at $18^{\circ} \mathrm{C}$ to stage 8 and pictures were taken of typical embryos. The titration of Pin1 and the mutants was essentially as described above except that the indicated protein was injected into one cell of the four-cell stage (18 embryos each Pin1 concentration) to the indicated final concentration and allowed to devel op for $3 \mathrm{hr}$. The cell cycle blocks by GST Pin1 were not homogeneous as cells that were injected with greater concentrations of GST-Pin1 were cleaved fewer times indicating a tighter cell cycle block. To be consistent, cell cycleblocked embryos were scored as those that contained at least one cell on the injected side that was more than five times larger than uninjected cells.

\section{Preparation of Xenopus CSF extracts}

Xenopus col ony-stimulation factor (CSF) extracts were prepared from unfertilized eggs, as described previously (Murray 1991) and used immediately. To examine the effect of Pinl on mitotic entry, a fresh CSF extract containing demembranated sperm $(150 / \mu \mathrm{l})$ and rhodamine-tubulin $(2 \mu \mathrm{g} / \mathrm{ml})$ was activated by ad- dition of $0.4 \mathrm{~mm}$ calcium chloride for $15 \mathrm{~min}$, before the indicated concentrations of various Pin1 proteins were added and mitotic entry was followed for 2 hr by nuclear morphology, nuclear envel ope breakdown, spindle formation, and C dc2 kinase activity, as described previously (Murray 1991). The cell cycle state of nuclei within the extracts were $>90 \%$ synchronous and typical nuclei were photographed.

\section{Synthesis of mitotic phosphoproteins}

The indicated mitotic phosphoproteins were translated in vitro using the TNT-coupled transcription/translation kit (Promega) in a total volume of $10 \mu \mathrm{l}$ in the presence of $8 \mu \mathrm{Ci}$ of [ $\left.{ }^{35} \mathrm{~S}\right] \mathrm{me}$ thionine $(1000 \mathrm{Ci} / \mathrm{mmole})$ for $2 \mathrm{hr}$ at $30^{\circ} \mathrm{C}$. They were then incubated in Xenopus interphase and mitotic extracts as described (Stukenberg et al. 1997). These incubated clones were precipitated by Pin1 beads as described below. The Xenopus Mos and Weel clones were a kind gift of M. Murakami, G. vande Woude (both at the $\mathrm{N}$ ational Cancer Institute, Frederick, MD) and J. Cooper (Fred Hutchinson Cancer Center, Seattle, WA); the Xenopus Cdc25 clone was a generous gift of W. Dunphy (C al ifornia Institute of T echnol ogy, Pasadena), T 3 and T3S2 Cdc25 mutants were kindly provided by J. Maller (Izumi and Maller 1993).

\section{Production of antibodies}

Because antibodies that we raised previously against carboxyterminal peptide of Pin1 (Lu et al. 1996) did not have a high sensitivity for detecting Pin1, especially for Xenopus Pin1, new Pin1 antibodies were produced, which recognize specifically a single 18-kD Pin1 protein in human cells and Xenopus extracts. To raise antibodies against Xenopus C dc25, recombinant GSTCdc25 (the clone was a kind gift of A. N ebrada and T. Hunt, Imperial Cancer Research Fund, South Mimms, Herts, UK) was affinity purified as described by the manufacturer (Pharmacia). The protein was further purified by SDS-PAGE and a gel slice containing $\mathrm{Cdc} 25$ was used to immunize rabbits.

GST pull-down, immunoprecipitation, and immunoblotting analysis

To detect Pin1-binding proteins, either HeLa cells were lysed in or Xenopus extracts were diluted in a buffer (buffer A) containing $50 \mathrm{~mm}$ Tris- $\mathrm{HCl}$ (pH 8.0), $200 \mathrm{~mm} \mathrm{~N} \mathrm{aCl}, 100 \mathrm{~mm} \mathrm{~N} \mathrm{aF}, 1 \mathrm{~mm}$ sodium orthovanadate, $10 \%$ glycerol, $1 \%$ Triton X-100, $10 \mu \mathrm{g} /$ $\mathrm{ml}$ of aprotinin, $50 \mu \mathrm{g} / \mathrm{ml}$ of PM SF, and $1 \mathrm{~mm}$ DTT. The lysates were preclarified with boiled Staphylococcus aureus bacteria (CalBiochem) and then incubated with $10 \mu \mathrm{l}$ of agarose beads containing various GST-Pin 1 proteins or control GST for $2 \mathrm{hr}$ at $4^{\circ} \mathrm{C}$. The precipitated proteins were washed five times in the same buffer and subjected to immunoblotting analysis. Immunoprecipitation and immunobl otting analysis using M PM -2 antibody (Davis et al. 1983), which was kindly provided by J. Kuang (M .D. Anderson Cancer Center, Houston, TX), Pinl antibodies (Lu et al. 1996; kindly provided by M. White (Joslin Diabetes Center, Boston, MA) or newly generated), anti-phosphorylated Tyr antibody (UBI), anti-Cdc25C (Ogg et al. 1994) (from H. Piwnica-Worms and Santa Cruz Biotechnology), antiCdc27 (Yu et al. 1998), anti-Plk1 (Zymed), anti-Cdc2 (Solomon et al. 1990), anti-human Myt1 (Booher et al. 1997), anti-human cyclin B1 (Pines and Hunter 1991), and anti-Xenopus cyclin B were performed, as described previously (Lu and Hunter 1995; Lu et al. 1996). 


\section{Coimmunoprecipitation of Pin1 and Cdc25}

To detect Pin 1 and $\mathrm{Cdc} 25$ interaction during the Xenopus cell cycle, 500 eggs were fertilized in a minimal volume of MMR [100 mM NaCl, $2 \mathrm{~mm} \mathrm{KCl}, 1 \mathrm{~mm} \mathrm{MgCl}_{2}, 2 \mathrm{M} \mathrm{CaCl}_{2}, 0.1 \mathrm{~mm}$ EDTA, 5 mM HEPES (pH 7.8)], diluted in $0.1 \times M M R$ for $10 \mathrm{~min}$, dejellied as described (Murray 1991) and incubated in CSF-XB [100 mM KCl, $0.1 \mathrm{~mm} \mathrm{CaCl} 2,2 \mathrm{~mm} \mathrm{M} \mathrm{gCl} 2,10 \mathrm{~mm} \mathrm{K-HEPES} \mathrm{(pH}$ 7.7), $50 \mathrm{~mm}$ sucrose, $5 \mathrm{~mm}$ EGTA (pH 7.7)]. At the indicated time after fertilization 15 eggs were crushed into $150 \mu$ l of ice cold CSF-XB with $1 \mu \mathrm{M}$ okadeic acid, microcentrifuged for 20 $\mathrm{sec}$, the layer between the yolk and the pellet was removed to a fresh chilled tube. This solution was mixed well and $5 \mu$ l was frozen in liquid nitrogen for future $\mathrm{H} 1$ kinase assays, and $30 \mu \mathrm{l}$ was diluted in $10 \mu \mathrm{l}$ of either $\alpha-\mathrm{Cdc} 25$ or control rabbit sera beads in $100 \mu \mathrm{l}$ of buffer A (containing $5 \mathrm{~mm}$ EDTA and $1 \mu \mathrm{M}$ microcystein but not vanadate). The immunoprecipitation reactions were rotated for $\sim 40 \mathrm{~min}$ at $4^{\circ} \mathrm{C}$, washed four times, and subjected to immunoblotting with anti-Pin1 antibodies. The associated Pin1 was quantified as described (Stukenberg et al. 1997). Although the amount of Pin1 bound to Cdc25 was barely above the detectable limit, the experiment was reproduced three times with similar results. In one case, a Pin1/Cdc25 complex remained high throughout mitosis.

\section{Cdc2 and Cdc25 assays}

$\mathrm{Cdc} 2$ was assayed using histone $\mathrm{H} 1$ as a substrate, as previously described (Murray 1991; Lu and Hunter 1995). Cdc25 activity was assayed by using the activation of its endogenous substrate, Cdc2/cyclin B complex phosphorylated on Thr-161, Tyr-15, Thr-14 as an indicator using a variation of an established protocol (Kumagai and Dunphy 1996). When cyclin B is added to a Xenopus interphase extract at levels insufficient to activate mitosis (referred to as a "subthreshold cyclin concentration"), the added cyclin $\mathrm{B}$ binds $\mathrm{Cdc} 2$ and the $\mathrm{Cdc} 2$ in the complex is phosphorylated by CAK, Weel, and Myt 1 to accumulate in an inactive form (Solomon et al. 1990). A subthreshold concentration of GST cyclin B $(10 \mu \mathrm{g})$ was added to $1 \mathrm{ml}$ of Xenopus interphase extract for $30 \mathrm{~min}$ at room temperature (Solomon et al. 1990). This was diluted eightfold in XB +3 mM DTT, rotated for $1 \mathrm{hr}$ with $3 \mathrm{ml}$ of GST agarose beads, washed three times in XBIP $(\mathrm{XB}+500 \mathrm{~mm} \mathrm{NaCl}$ and $1 \% \mathrm{~N} \mathrm{P}-40+2 \mathrm{~mm}$ DTT), washed two times (once overnight) in EB (80 mM $\beta$-glycerol phosphate, 15 mM EGTA, $15 \mathrm{~mm} \mathrm{M} \mathrm{gCl}_{2}+2 \mathrm{~mm}$ DTT, $500 \mathrm{~mm} \mathrm{NaCl}$, and $1 \%$ N P-40, and finally twice with EB +10 mM DTT). These Cdc25 assay beads were stored at $4^{\circ} \mathrm{C}$ for up to 1 month.

M itotic GST-Cdc 25 was purified by incubating $22 \mu \mathrm{g}$ of GST$\mathrm{Cdc} 25$ in a Xenopus mitotic extract for $30 \mathrm{~min}$ at $23^{\circ} \mathrm{C}$; this was diluted eightfold in XB and rotated with $50 \mu$ of glutathioneagarose beads (Sigma) for $1 \mathrm{hr}$ at $4^{\circ} \mathrm{C}$. The beads were washed five times in XB-IP, twice in XB +2 mM DTT, and eluted in 25 $\mu \mathrm{X} X \mathrm{~B}+2 \mathrm{~mm}$ reduced GSH. The final concentration of mitotic GST-Cdc25 was $0.36 \mathrm{mg} / \mathrm{ml}$. A 27-fold dilution of this mitotic GST-Cdc25 could fully activate Cdc2 in the assay below, whereas GST-Cdc25 isolated from interphase extracts in parallel lost activity after a threefold dilution (data not shown). Thus, the mitotic extract stimulated the $\mathrm{Cdc} 25$ at least nine times over interphase extracts as previously reported (Solomon et al. 1990).

To assay Cdc25 activity $1 \mu \mathrm{M}$ mitotic GST Cdc25, and the indicated concentration of either Pin1, Pin1 ${ }^{\text {R68,69A }}$, or BSA were incubated in a $20-\mu$ reaction in $X B+1 \mathrm{mM}$ ATP for $10 \mathrm{~min}$ at room temperature. These reactions were diluted sequentially $(1: 1,1: 3,1: 9,1: 27)$ into XB $+1 \mathrm{~mm}$ ATP and $10 \mu \mathrm{l}$ of each was mixed with $10 \mu \mathrm{l}$ of $\mathrm{Cdc} 25$ assay beads for $10 \mathrm{~min}$ at room temperature with constant shaking. Subsequently, the Cdc25 assay beads were washed three times in XB-IP, twice in EB +1 $\mathrm{mM}$ DTT, and assayed for $\mathrm{H} 1$ kinase activity as described (SoIomon et al. 1990). Phosphorlmager analysis of the $\mathrm{H} 1$ kinase assays were quantified by the $\mathrm{M}$ ol ecular Dynamics ImageQuant 3.3 software. Figure 8A shows an assay with $1 \mu \mathrm{m}$ mitotic GST Cdc25, $0.67 \mu \mathrm{M}$ of either Pin1, Pin1 ${ }^{\text {R68,69A }}$ or $16 \mu \mathrm{M}$ BSA then diluted 27 -fold before being mixed with the $\mathrm{Cdc} 25$ assay beads and the amount of $\mathrm{HI}$ kinase activity is relative to the amount of activity of the beads without Cdc25 being zero and the BSA reaction being $100 \%$. The most reproducible way to quantify the Cdc25 activity in this assay was by determining the endpoint dilution of $\mathrm{Cdc} 25$ that could activate $\mathrm{Cdc} 2$. Therefore, the Cdc25 activity in Figure 8B is quantified by the end-point dilution of the mitotic GST-Cdc25 at which Cdc2 on the beads could still be significantly activated.

\section{Acknowledgments}

We are grateful to B. Neel, L. Cantley, J. Kuang, T. M eans, S. Kornbluth, J. Noel, and T. Hunter for helpful discussions. Experiments to determine Pin1 levels during the cell cycle were done in T. Hunter's laboratory. Thanks al so go to J. Kuang, $M$. White, W. Dunphy, H. Piwnica-Worms, J. Maller, T. Hunt, J. Cooper, M. M urakami, G. vande Woude, L. Cantley, and B. N eel for kindly providing various reagents, to $G$. Tucker-Kellogg and C. Walsh for use of their PPlase assay facility and kinetic analysis program, to Kim Goslin and Kevin Lustig for preparation of Xenopus oocytes and to Tonya Civco for technical help and taking care of frogs. P.T.S. is supported by The Charles A. King Trust. The work performed is supported by the U.S. Public Health Service grants R01GM26875 to M.W.K. and R01GM 56230 to K.P.L.

The publication costs of this article were defrayed in part by payment of page charges. This article must therefore be hereby marked "advertisement" in accordance with 18 USC section 1734 solely to indicate this fact.

\section{References}

Bailly, E., M. M cCaffrey, N. Touchot, A. Zahraoui, B. Goud, and M. Bornens. 1991. Phosphorylation of two small GTP-binding proteins of the Rab family by p34cdc2. Nature 350: 715718.

Blangy, A., H.A. Lane, P. d'Herin, M. Harper, M. Kress, and E.A. Nigg. 1995. Phosphorylation by p34cdc2 regulates spindle association of human Eg5, a kinesin-related motor essential for bipolar spindle formation in vivo. Cell 83: 1159-1169.

Booher, R.N., P.S. Holman, and A. Fattaey. 1997. Human M yt1 is a cell cycle-regulated kinase that inhibits $\mathrm{Cdc} 2$ but not Cdk2 activity. J. Biol. Chem. 272: 22300-22306.

Coleman, T.R. and W.G. Dunphy. 1994. Cdc2 regulatory factors. Curr. Opin. Cell Biol. 6: 877-882.

Coleman, T.R., Z. Tang, and W.G. Dunphy. 1993. Negative regulation of the weel protein kinase by direct action of the nim1/cdr1 mitotic inducer. Cell 72: 919-929.

Davis, F.M., T.Y. Tsao, S.K. Fowler, and P.N. Rao. 1983. M onoclonal antibodies to mitotic cells. Proc. Natl. Acad. Sci. 80: 2926-2930.

Davis, F.M., D.A. Wright, J.E. Penkala, and P.N. Rao. 1989. Mitosis-specific monoclonal antibodies block cleavage in amphibian embryos. Cell Struct. Funct. 14: 271-217.

Fischer, G. 1994. Peptidyl-prolyl cis/trans isomerases. Angew. Chem. Intl. Ed. Engl. 33: 1415-1436.

Golsteyn, R.M., K.E. Mundt, A.M. Fry, and E.A. Nigg. 1995. Cell 
cycle regulation of the activity and subcellular localization of PIk1, a human protein kinase implicated in mitotic spindle function. J. Cell Biol. 129: 1617-1628.

Hamanaka, R., M.R. Smith, P.M. O'Connor, S. Maloid, K. M ihalic, J.L. Spivak, D.L. Longo, and D.K. Ferris. 1995. Pololike kinase is a cell cycle-regulated kinase activated during mitosis. J. Biol. Chem. 270: 21086-21091.

Hanes, S.D., P.R. Shank, and K.A. Bostian. 1989. Sequence and mutational analysis of ESS1, a gene essential for growth in Saccharomyces cerevisiae. Yeast 5: 55-72.

Heald, R. and F. McKeon. 1990. Mutations of phosphorylation sites in lamin A that prevent nuclear lamina disassembly in mitosis. Cell 61: 579-589.

Hecht, R.M., M. Berg-Zabelshansky, P.N . Rao, and F.M. Davis. 1987. Conditional absence of mitosis-specific antigens in a temperature sensitive embryonic-arrest mutant of Caenorhabditis elegans. J. Cell Sci. 87: 305-314.

Heintz, N., H.L. Sive, and R.G. Roeder. 1983. Regulation of human histone gene expression: Kinetics of accumulation and changes in the rate of synthesis and in the half-lives of individual histone mRN As during the HeLa cell cycle. Mol. Cell. Biol. 3: 539-550.

Hirano, T. and T.J. Mitchison. 1991. Cell cycle control of higher-order chromatin assembly around naked DNA in vitro. J. Cell Biol. 115: 1479-1489.

Izumi, T. and J.L. Maller. 1993. Elimination of cdc2 phosphorylation sites in the cdc25 phosphatase blocks initiation of M-phase. Mol. Biol. Cell. 4: 1337-1350.

Izumi, T., D.H. Walker, and J.L. Maller. 1992. Periodic changes in phosphorylation of the Xenopus cdc25 phosphatase regulate its activity. Mol. Biol. Cell. 3: 927-939.

Johnson, R.T. and P.N. Rao. 1970. Mammalian cell fusion: Induction of premature chromosome condensation in interphase nuclei. Nature 226: 717-722.

Keryer, G., F.M. Davis, P.N. Rao, and J. Beisson. 1987. Protein phosphorylation and dynamics of cytoskel etal structures associated with basal bodies in Paramecium. Cell Motil. Cytoskel eton 8: 44-54.

King, R.W., P.K. Jackson, and M.W. Kirschner. 1994. Mitosis in transition. Cell 79: 563-571.

King, R.W., J.M. Peters, S. Tugendreich, M. Rolfe, P. Hieter, and M.W. Kirschner. 1995. A 20 S complex containing CDC27 and CDC16 catalyzes the mitosis-specific conjugation of ubiquitin to cyclin B. Cell 81: 279-288.

Krek, W. and E.A. Nigg. 1991. Mutations of p34cdc2 kinase activation in vertebrates. EMBO J. 10: 3331-3341.

Kuang, J. and C.L. Ashorn. 1993. At least two kinases phosphorylate the M PM -2 epitope during Xenopus oocyte maturation. J. Cell Biol. 123: 859-868.

Kuang, J., J.Y. Zhao, D.A. Wright, G.F. Saunders, and P.N. Rao. 1989. Mitosis specific monoclonal antibody M PM -2 inhibits Xenopus oocyte maturation and depletes maturation promoting activity. Proc. Natl. Acad. Sci. 86: 4982-4986.

Kuang, J., C.L. Ashorn, M. Gonzalez-Kuyvenhoven, and J.E. Penkala. 1994. cdc25 is one of the M PM-2 antigens involved in the activation of maturation-promoting factor. Mol. Biol. Cell. 5: 135-145.

Kumagai, A. and W.G. Dunphy. 1996. Purification and molecuIar cloning of PIx1, a Cdc25-regulatory kinase from Xenopus egg extracts. Science 273: 1377-1380.

Lee, T.H., C. Turck, and M.W. Kirschner. 1994. Inhibition of cdc2 activation by IN H/PP2A. Mol. Biol. Cell. 5: 323-338.

Lu, K.P. and T. Hunter. 1995. Evidence for a N IM A-like mitotic pathway in vertebrate cells. Cell 81: 413-424.

Lu, K.P., S.A. Osmani, and A.R. Means. 1993. Properties and regulation of the cell cycle-specific NIMA protein kinase of
Aspergillus nidulans. J. Biol. Chem. 268: 8769-8776.

Lu, K.P., S.D. Hanes, and T. Hunter. 1996. A human peptidylprolyl isomerase essential for regulation of mitosis. Nature 380: 544-547.

M al eszka, R., S.D. Hanes, R.L. Hackett, C.H. de Couet, and G.L. Miklos. 1996. The Drosophila melanogaster dodo (dod) gene, conserved in humans, is functionally interchangeable with the ESS1 cell division gene of Saccharomyces cerevisiae. Proc. Natl. Acad. Sci. 93: 447-451.

M atsumoto-Taniura, N., F. Pirollet, R. M onroe, L. Gerace, and J.M. Westendorf. 1996. Identification of novel M phase phosphoproteins by expression cloning. Mol. Biol. Cell. 7: 14551469.

Mueller, P.R., T.R. Coleman, A. Kumagai, and W.G. Dunphy. 1995. Myt1: A membrane-associated inhibitory kinase that phosphorylates $\mathrm{Cdc} 2$ on both threonine-14 and tyrosine-15. Science 270: 86-90.

Murray, A.W. 1991. Cell cycle extracts. Methods Cell. Biol. 36: 581-605.

Muslin, A.J., J.W. Tanner, P.M. Allen, and A.S. Shaw. 1996. Interaction of 14-3-3 with signaling proteins is mediated by the recognition of phosphoserine. Cell 84: 889-897.

Nigg, E.A. 1995. Cyclin-dependent protein kinases: Key regulators of the eukaryote cell cycle. BioEssays 17: 471-480.

N urse, P. 1994. Ordering S phase and M phase. Cell 79: 547-550.

Ogg, S., B. Gabrielli, and H. Piwnica-Worms. 1994. Purification of a serine kinase that associates with and phosphorylates human Cdc25C on serine 216. J. Biol. Chem. 269: 3046130469.

Pawson, T. 1995. Protein modules and signalling networks. Nature 373: 573-580.

Pines, J. and T. Hunter. 1991. Human cyclins A and B1 are differentially located in the cell and undergo cell cycle-dependent nuclear transport. J. Cell Biol. 115: 1-17.

Poon, R.Y., H. Toyoshima, and T. Hunter. 1995. Redistribution of the CDK inhibitor p27 between different cyclin.CDK complexes in the mouse fibroblast cell cycle and in cells arrested with lovastatin or ultraviolet irradiation. Mol. Biol. Cell. 6: 1197-1213.

Ranganathan, R., K.P. Lu, T. Hunter, and J.P. N oel. 1997. Structural and functional analysis of the mitotic peptidyl-prolyl isomerase Pinl suggests that substrate recognition is phosphorylation dependent. Cell 89: 875-886.

Renzi, L., M.S. Gersch, M.S. Campbell, L. Wu, S.A. Osmani, and G.J. Gorbsky. 1997. M PM-2 antibody-reactive phosphorylations can be created in detergent- extracted cells by kinetochore-bound and soluble kinases. J. Cell. Sci. 110: 20132025.

Reynisdottir, I. and J. Massague. 1997. The subcellular locations of p15(Ink4b) and p27(Kip1) coordinate their inhibitory interactions with cdk4 and cdk2. Genes \& Dev. 11: 492-503.

Russell, P. and P. N urse. 1986. cdc25+functions as an inducer in the mitotic control of fission yeast. Cell 45: 145-153.

Schmid, F.X. 1995. Prolyl isomerases join the fold. Curr. Biol. 5: 993-994.

Schreiber, S.L. 1991. Chemistry and biology of the immunophilins and their immunosuppressive ligands. Science 251: 283287.

Solomon, M.J., M. Glotzer, T.H. Lee, M. Philippe, and M.W. Kirschner. 1990. Cyclin activation of p34cdc2. Cell 63: 1013-1024.

Strausfeld, U., A. Fernandez, J.P. Capony, F. Girard, N. Lautredou, J. Derancourt, J.C. Labbe, and N.J. Lamb. 1994. Activation of p34cdc2 protein kinase by microinjection of human cdc25C into mammalian cells. Requirement for prior phosphorylation of $\operatorname{cdc} 25 \mathrm{C}$ by p34cdc2 on sites phosphory- 
Shen et al.

lated at mitosis. J. Biol. Chem. 269: 5989-6000.

Stukenberg, P.T., K.D. Lustig, T.J. McGarry, R.W. King, J. Kuang, and M.W. Kirschner. 1997. Systematic identification of mitotic phosphoproteins. Curr. Biol. 7: 338-348.

Taagepera, S., P.N. Rao, F.H. Drake, and G.J. Gorbsky. 1993. DNA topoisomerase II al pha is the major chromosome protein recognized by the mitotic phosphoprotein antibody M PM-2. Proc. Natl. Acad. Sci. 90: 8407-8411.

Taagepera, S., P. Dent, J.H. Her, T.W. Sturgill, and G.J. Gorbsky. 1994. The M PM-2 antibody inhibits mitogen-activated protein kinase activity by binding to an epitope containing phosphothreonine-183. Mol. Biol. Cell. 5: 1243-1251.

Vandre, D.D., F.M. Davis, P.N. Rao, and G.G. Borisy. 1984. Phosphoproteins are components of mitotic microtubule organizing centers. Proc. Natl. Acad. Sci. 81: 4439-4443.

Vandre, D.D., F.M. Davis, P.N. Rao, and G.G. Borisy. 1986. Distribution of cytoskeletal proteins sharing a conserved phosphorylated epitope. Eur. J. Cell. Biol. 41: 72-81.

Vandre, D.D., V.E. Centonze, J. Peloquin, R.M. Tombes, and G.G. Borisy. 1991. Proteins of the mammalian mitotic spindle: phosphorylation/dephosphorylation of MAP-4 during mitosis. J. Cell Sci. 98: 577-588.

Westendorf, J.M., P.N. Rao, and L. Gerace. 1994. Cloning of cDNAs for $M$-phase phosphoproteins recognized by the M PM 2 monoclonal antibody and determination of the phosphorylated epitope. Proc. Natl. Acad. Sci. 91: 714-718.

Wordeman, L., F.M. Davis, P.N. Rao, and W.Z. Cande. 1989. Distribution of phosphorylated spindle-associated proteins in the diatom Stephanopyxis turris. Cell. Motil. Cytoskeleton 12: 33-41.

Yaffe, M.B., M. Schutkowski, M. Shen, X.Z. Zhou, P.T. Stukenberg, J. Rahfeld, J. Xu, J. Kuang, M.W. Kirschner, G. Fischer, L.C. Cantley, and K.P. Lu. 1997. Sequence-specific and phosphorylation-dependent proline isomerization: A potential mitotic regulatory mechanism. Science 278:1957-1960.

Ye, X.S., G. Xu, R.T. Pu, R.R. Fincher, S.L. McGuire, A.H. Osmani, and S.A. Osmani. 1995. The NIMA protein kinase is hyperphosphorylated and activated downstream of p34cdc2/ cyclin B: coordination of two mitosis promoting kinases. EMBO J. 14: 986-994.

Yu, H., J.M. Peters, R.W. King, A. Page, P. Hieter, and M.W. Kirschner. 1988. Identification of a cullin homology regtion in a subunit of the anaphase-promoting complex. Science (in press). 


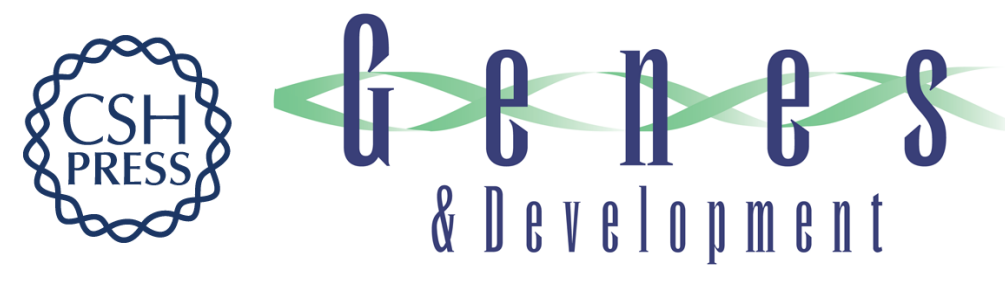

\section{The essential mitotic peptidyl-prolyl isomerase Pin1 binds and regulates mitosis-specific phosphoproteins}

Minhui Shen, P. Todd Stukenberg, Marc W. Kirschner, et al.

Genes Dev. 1998, 12:

References This article cites 59 articles, 31 of which can be accessed free at:

http://genesdev.cshlp.org/content/12/5/706.full.html\#ref-list-1

License

Email Alerting Receive free email alerts when new articles cite this article - sign up in the box at the top Service right corner of the article or click here.

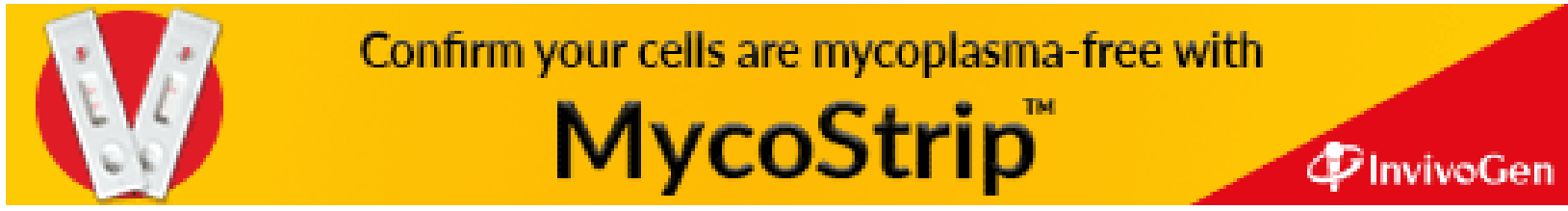

